\title{
Association analysis of low-phosphorus tolerance in West African pearl millet using DArT markers
}

\author{
D. C. Gemenet - W. L. Leiser - R. G. Zangre - I. I. Angarawai • \\ M. D. Sanogo • O. Sy • T. Mahendar • C. T. Hash • \\ B. I. G. Haussmann
}

Received: 17 January 2015 / Accepted: 24 July 2015

(C) Springer Science+Business Media Dordrecht 2015

\begin{abstract}
Pearl millet [Pennisetum glaucum (L.) R. $\mathrm{Br}$.] is a food security crop in the harshest agricultural regions of the world. While low soil phosphorus (P) availability is a big constraint on its production, especially in West Africa (WA), information on genomic regions responsible for low-P tolerance in pearl millet is generally lacking. We present the first report on genetic polymorphisms underlying several plant P-related parameters, flowering time (FLO) and grain yield (GY) under P-limiting conditions based on 285 diversity array technology markers and 151 West African pearl millet inbred lines phenotyped in six
\end{abstract}

Electronic supplementary material The online version of this article (doi:10.1007/s11032-015-0361-y) contains supplementary material, which is available to authorized users.

D. C. Gemenet · W. L. Leiser · B. I. G. Haussmann ( $₫)$ Institute of Plant Breeding, Seed Science and Population Genetics, University of Hohenheim, Fruwirthstr. 21, 70599 Stuttgart, Germany

e-mail: Bettina.haussmann@uni-hohenheim.de

D. C. Gemenet

Kenya Agricultural and Livestock Research Organization, PO Box 57811, Nairobi 00200, Kenya

R. G. Zangre

Institut de 1'Environnement et de Recherches Agricoles (INERA), Ouagadougou, Burkina Faso

I. I. Angarawai · C. T. Hash

International Crops Research Institute for the Semi-Arid

Tropics (ICRISAT) Sahelian Center, Niamey, Niger environments in WA under both high-P and low-P conditions. Nine markers were significantly associated with P-related traits, nine markers were associated with FLO, whereas 13 markers were associated with GY each explaining between 5.5 and $15.9 \%$ of the observed variation. Both constitutive and adaptive associations were observed for FLO and GY, with markers $\mathrm{PgPb1} 1603$ and $\mathrm{PgPb12954}$ being associated with the most stable effects on FLO and GY, respectively, across locations. There were a few shared polymorphisms between traits, especially P-efficiency-related traits and GY, implying possible colocation of genomic regions responsible for these traits. Our findings help bridge the gap between quantitative and molecular methods of studying complex traits like low-P tolerance in WA. However, validation of these markers is necessary to

M. D. Sanogo

Institut d'Economie Rurale (IER), Cinzana, Mali

O. Sy

Institut Sénégalais de Recherches Agricoles (ISRA), Bambey, Senegal

T. Mahendar

The Genomics Service Laboratory, M.S. Swaminathan Center of Excellence in Genomics, ICRISAT, Hyderabad, India 
determine their potential applicability in marker-assisted selection programs targeting low-P environments, which are especially important in WA where resourcepoor farmers are expected to be the hardest hit by the approaching global $\mathrm{P}$ crisis.

Keywords Low phosphorus availability - West Africa $\cdot$ Marker-trait association · DArT markers

\section{Introduction}

Pearl millet [Pennisetum glaucum (L.) R. Br., syn. Cenchrus americanus (L.) Morrone], $(2 \mathrm{n}=2 \mathrm{x}=14)$ is the sixth most important global cereal crop. It is produced as a rain-fed grain and fodder crop in the hottest, driest regions of sub-Saharan Africa and the Indian subcontinent (Andrews and Kumar 1992; Sehgal et al. 2012). It is the most important cereal for food security in the West African Sudano-Sahelian belt, where it is grown as a staple crop by some of the poorest people of the world (Haussmann et al. 2012). Pearl millet ensures food security by providing both calories and essential micronutrients more reliably than any other cereal under dryland conditions in these regions (Goswami et al. 1969; Sawaya et al. 1984; Stich et al. 2010; Sehgal et al. 2012). Despite its importance, its production within this region is hampered by erratic rainfall, acidic soils and low soil fertility among other production constraints (Brück et al. 2003). The importance of low soil phosphorus (P) availability on yield reduction is well documented within the region (Bationo et al. 1986, 1990; Bationo and Mokwunye 1991; Payne et al. 1991; Rebafka et al. 1994; Muehlig-Versen et al. 2003). Given the economic constraints related to fertilizer access within this region, it is therefore imperative that plant breeders put more efforts into developing pearl millet varieties that are tolerant to low soil P conditions (Hash et al. 2002). Recently, genetic variation for performance under low-P conditions was reported in West African pearl millet open-pollinated varieties, inbred lines and testcrosses, where direct selection under low-P conditions was shown to have potential for improving pearl millet grain yield in P-limited environments (Gemenet et al. 2014, 2015a, 2015b). Given the difficulties associated with field evaluation for low-P tolerance due to numerous interactions with drought and other soil properties in WA, marker-assisted selection would assist in shortening the breeding process targeting low-P environments.

Marker-assisted selection has the potential to expedite the breeding process, but requires proper estimation of the positions and effects of quantitative trait loci (QTLs; Stich et al. 2008; Supriya et al. 2011). Since the 1990s, several reports about QTL mapping P-deficiency tolerance have been published and QTLs for P-deficiency tolerance-related traits have been mapped in several crops including maize (Reiter et al. 1991; Chen et al. 2009; Li et al. 2010; Zhang et al. 2014), rice (Wissuwa et al. 1998, 2002), soybean (Li et al. 2005) and common bean (Yan et al. 2001; Beebe et al. 2006). Although the prospects of marker-assisted selection to enhance performance under low-P conditions in 'orphan crops' have been clearly outlined by Hash et al. (2002), not much previous effort has gone into identifying genomic regions responsible for P-deficiency tolerance-related traits in pearl millet. Most efforts in biparental QTL mapping in pearl millet have been directed toward drought tolerance (Yadav et al. 2002, 2004; Sehgal et al. 2012) and downy mildew resistance (Jones et al. 1995, 2002; Hash et al. 1995; Hash and Witcombe 2001; Breese et al. 2002; Gulia et al. 2007) and demonstrations of the effectiveness of marker-assisted selection for these traits (Bidinger et al. 2005; Hash et al. 2006a, b; Khairwal and Hash 2007; Kholová et al. 2010a, b; Nepolean et al. 2009; Serraj et al. 2005). Association mapping utilizes ancestral recombination in natural populations to overcome the limitations associated with classical linkage mapping of reduced resolution of biparental mapping populations due to small population sizes and modest degrees of recombination (Flint-Garcia et al. 2003, 2005: Kraakman et al. 2004; Stich et al. 2008). Using association mapping, Leiser et al. (2014) and Hufnagel et al. (2014) have detected several genomic regions in sorghum associated with various low-P tolerance traits at different stages of crop maturity.

The ability to identify useful phenotype-genotype associations through association analysis can be limited by several factors including population structure leading to high false positives, extended linkage disequilibrium (LD) blocks resulting from selective events or stochastic probabilities, and epistasis as well as rare causal alleles that require large populations for detection (Chan et al. 2010) and/or are better addressed using targeted biparental mapping populations. Having been domesticated in the Sahelian zone 
of West Africa (WA; Harlan et al. 1976; Tostain 1992; Mariac et al. 2006; Manning 2011), cultivated pearl millet displays tremendous phenotypic variability for traits such as flowering time, panicle length, grain and stover characteristics, tolerance to drought, pests and diseases, as well as nutritional value (Bhattacharjee et al. 2007; Stich et al. 2010; Bashir et al. 2014a, 2014b; Pucher et al. 2014, 2015). This can be attributed to genetic differentiation as a consequence of many factors including local adaptation, selection and genetic drift, which can lead to non-random distribution of important agronomic traits (Hedrick 2005; Lewis 2010). Despite this large variation, it has been established that neither country of origin nor agroecological zone shows a clear differentiation of pearl millet landrace genotypes (probably due to their highly cross-pollinated breeding behavior and robust wind-borne pollen); but rather, populations are differentiated into subgroups based on their parentage and/ or similar agronomic traits (Tostain et al. 1987; Oumar et al. 2008; Stich et al. 2010; Bashir et al. 2015).

Due to their high polymorphic information content, simple sequence repeat markers (SSRs) have been applied as markers of choice in most pearl millet genetic diversity studies (Vigouroux et al. 2005; Mariac et al. 2006; Kapila et al. 2008; Lewis 2010; Stich et al. 2010; Gupta et al. 2012; Nepolean et al. 2012). Only one published study has applied diversity array technology (DArT) markers in pearl millet genetic diversity analysis and/or linkage map saturation (Supriya et al. 2011; Kholová et al. 2012), despite it being shown that their cost per data point is about one-tenth that of SSRs (Xia et al. 2005). A pearl millet DArT platform has been developed in the M.S. Swaminathan Center of Excellence in Genomics at the Indian headquarters of the International Crops Research Institute for the Semi-Arid Tropics (ICRISAT; Supriya et al. 2011). DArT is a costeffective, solid-state platform, hybridization-based marker technology offering high multiplexing without prior sequence information (Jaccoud et al. 2001; Wenzl et al. 2004; Supriya et al. 2011) and is the least expensive way to achieve genome-wide marker coverage without extensive DNA sequence data. Since their initial development in rice, DArT markers have gained importance in genetic mapping, genotyping and diversity assessment in many important crops such as barley (Wenzl et al. 2004), cassava (Hurtado et al. 2008), pigeon pea (Yang et al. 2006), wheat (Zhang et al. 2011), sorghum (Mace et al. 2008), oat (Tinker et al. 2009), rye
(Bolibok-Bragoszewska et al. 2009), Triticum monoccocum (Jing et al. 2009) and white lupin (Raman et al. 2014).

The main objective of the present study therefore was to identify genetic regions underlying quantitative traits under low-P conditions such as $\mathrm{P}$ concentration in stover (PCS), $\mathrm{P}$ concentration in grain (PCG), P-uptake efficiency (PBM), P-utilization efficiency (PUE), time to $50 \%$ flowering (FLO) and grain yield (GY). We specifically provide an overview of population structure, we examine linkage disequilibrium in the association study panel, and we identify DArT markers associated with the traits mentioned above.

\section{Materials and methods}

\section{Phenotypic evaluation}

A total of 155 inbred lines (Online Resource 1) derived from West and Central African landraces (openpollinated varieties) were evaluated in multiple field trials in four WA countries, namely Burkina Faso (Gampela; $12^{\circ} 25^{\prime} 51^{\prime \prime} \mathrm{N} ; 1^{\circ} 22^{\prime} 18^{\prime \prime} \mathrm{W}$ ), Niger (Sadoré; $17^{\circ} 36^{\prime} 28.04^{\prime \prime} \mathrm{N} ; \quad 8^{\circ} 4^{\prime} 53.99^{\prime \prime} \mathrm{W}$ ), Mali (Koporo; $14^{\circ} 3^{\prime} 49.9^{\prime \prime} \mathrm{N} ; 3^{\circ} 4^{\prime} 31^{\prime \prime} \mathrm{W}$ ) and Senegal (Bambey; $14^{\circ} 42^{\prime} 2.66^{\prime \prime} \mathrm{N}, 16^{\circ} 27^{\prime} 32.8^{\prime \prime} \mathrm{W}$ ) in the rainy seasons (RS) of 2011 and 2012 under two P-level treatments: high P (HP; with P fertilization) and low P (LP; without P fertilization). Since pearl millet is naturally outcrossing, the open-pollinated varieties experienced a high degree of inbreeding depression, and as a result, the inbred lines were developed using initial selfing for three generations, followed by two generations of sibbing and then a last generation of selfing. The trials were sown side by side in $\alpha$-lattices with three replications within each P-fertilization level. Individual plot size was $3.6 \mathrm{~m}^{2}$, which comprised of a single-row plot of 7 hills with $0.8 \mathrm{~m}$ intra- and $0.75 \mathrm{~m}$ inter-row spacing. Trials were rainfed, with total locational rainfall ranging from 466 to $950 \mathrm{~mm}$ across the location $\times$ year combinations. Initial soil testing was done by sampling the top $20 \mathrm{~cm}$ and analyzing for $\mathrm{pH}$, total nitrogen, organic carbon, Bray1-P and exchangeable potassium; $\mathrm{pH}$ ranged from 4.6 to 6.6 , total nitrogen ranged from 83 to $370 \mathrm{mg} \mathrm{N} \mathrm{kg}^{-1}$ soil, organic carbon ranged from 0.11 to $0.41 \%$, Bray1-P ranged from 3.0 to $7.7 \mathrm{mg} \mathrm{P} \mathrm{kg}^{-1}$ soil, and exchangeable potassium ranged from 0.11 to $0.47 \mathrm{cmol}^{+} \mathrm{kg}^{-1}$ soil. The soil sampling was carried out 
by taking five representative samples per replication in each P-level, which were then mixed and soil analysis was done for each replication for each P-level. Growing conditions for these field trials are described in detail in Gemenet et al. (2014). In RS 2011, the HP treatment received a basal $20 \mathrm{~kg} \mathrm{P}^{-1}$ and $18 \mathrm{~kg} \mathrm{~N} \mathrm{ha}^{-1}$ [as $100 \mathrm{~kg} \mathrm{ha}^{-1}$ diammonium phosphate (DAP)], whereas the LP treatment was only supplied with $18 \mathrm{~kg} \mathrm{~N} \mathrm{ha}^{-1}$ (as $39 \mathrm{~kg} \mathrm{ha}^{-1}$ urea). Two top dressings, of $16 \mathrm{~kg} \mathrm{~N} \mathrm{ha}^{-1}$ (as $35 \mathrm{~kg} \mathrm{ha}^{-1}$ urea) each, were supplied to each plot at 30 and 45 days after sowing. Drought that occurred early in the season within the region in RS 2011 caused delay of fertilizer applications to the trials by up to 2 weeks after sowing to avoid burning the seedlings. Based on the results from RS 2011, and concerns over a masked P effect, in RS 2012 the HP treatment received a basal $40 \mathrm{~kg} \mathrm{P}^{-1}$ [as $100 \mathrm{~kg} \mathrm{ha}^{-1} \mathrm{DAP}+255.56$ $\mathrm{kg} \mathrm{ha}^{-1}$ single super phosphate (SSP)] and $18 \mathrm{~kg} \mathrm{~N}^{-1}$ (as $39 \mathrm{~kg} \mathrm{ha}^{-1}$ urea) followed by four topdressings with $11.4 \mathrm{~kg} \mathrm{~N}^{-1}$ (as $25 \mathrm{~kg} \mathrm{ha}^{-1}$ urea) at 3, 5, 7 and 9 weeks after sowing. Data collected include time to $50 \%$ flowering (FLO; days from sowing to full female stigma emergence on $50 \%$ of the main stem panicles per plot) and grain yield (GY; $\mathrm{g} \mathrm{m}^{-2}$ ). In addition, $\mathrm{P}$ concentration in stover (PCS; $\mathrm{mg} \mathrm{g}^{-1}$ ) and $\mathrm{P}$ concentration in grain (PCG; $\mathrm{mg} \mathrm{g}^{-1}$ ) were measured using an inductively coupled plasma emission spectrometer (ICP-OES) according to VDLUFA (2011) using air-dried samples obtained from the Sadoré $2011 \mathrm{HP}$ and LP trials. $\mathrm{P}$ uptake (PBM, $\mathrm{mg} \mathrm{m}^{-2}$ ) was then conservatively calculated as the sum of total $\mathrm{P}$ in grain $\left(\mathrm{PCG}^{*} \mathrm{GY} ; \mathrm{mg} \mathrm{m}^{-2}\right.$ ) and total $\mathrm{P}$ in stover $\left(\mathrm{PCS} * \mathrm{SWT} ; \mathrm{mg} \mathrm{m}^{-2}\right.$, where SWT $=$ stover weight, obtained by air drying the stover per plot to constant weight). P-utilization efficiency (PUE) was calculated as the ratio of grain yield and total $\mathrm{P}$ uptake (GY/PBM; $\mathrm{g} \mathrm{mg}^{-1} \mathrm{P}$ ). Field evaluation of the inbred lines for $\mathrm{GY}$ is discussed in detail in Gemenet et al. (2014), whereas P uptake and PUE of the inbred lines is discussed in detail in Gemenet et al. (2015a).

\section{Genotypic evaluation}

DNA was extracted from leaves of a single 3-week-old plant per inbred line using the QIAGEN DNeasy miniplant kit. DArT marker genotyping was done by the Genomics Service Laboratory of the M.S. Swaminathan Center of Excellence in Genomics, which is located on the Patancheru campus of the International Crops
Research Institute for the Semi-Arid Tropics (ICRISAT), in Hyderabad, India. DArT analysis involves reducing the complexity of a DNA sample to obtain a 'representation' mainly based on restriction, adapter ligation and then amplification. The reasoning behind this is that a representation contains two types of fragments: common fragments for a species and variable fragments present in some but not in other individuals of a species. The second category is considered as DArT markers, and once a library of a species is formed (DArT array), the presence/absence of the variable markers can be scored in any representation hybridized to the DArT array. A DArT array for pearl millet was developed at ICRISAT, India, based on diverse genotypes representing the diversity of pearl millet accessions held at the GenBank using the Pst1based complexity reduction method by Wenzl et al. (2004). The complete method description of the pearl millet DArT array development is given in Supriya et al. (2011). For analysis of our inbred lines panel, genomic representations were generated for each of our inbred lines as described by Supriya et al. (2011). The representations were then hybridized to the pearl millet DArT array, and polymorphic markers were scored ' 1 ' for presence and ' 0 ' for absence using DArTsoft as described in Supriya et al. (2011). The DArTsoft generated ' 1 ' and ' 0 ' scores were provided for a total of 407 DArT markers that were $100 \%$ reproducible with the DNA samples provided, with call rates ranging from 75.0 to $98.2 \%$ and polymorphic information content (PIC) values ranging from 0.10 to 0.50 with an average of 0.35 . The number of markers was reduced to 285 by restricting the minimum call rate to $\geq 90 \%$ per marker. The list of markers used in the present study is provided in Online Resource 2, and more details concerning the clones from which the present markers were developed can be requested from the Genomics Service Laboratory of the M.S. Swaminathan Center of Excellence in Genomics. The 285 markers were used in further analysis with 151 genotypes (four genotypes were excluded due to too much missing genotypic data).

Data analysis

\section{Phenotypic data analysis}

Analysis of the phenotypic data was based on REML mixed models in GENSTAT 17th edition. Data from Koporo 2012 and Bambey 2012 were left out from 
analysis due to too many missing data points as a result of too much rainfall directly after sowing with concomitant soil erosion/compaction that affected trial establishment. In order to avoid double shrinkage associated with the use of best linear unbiased predictors (BLUPs) in association analysis (Piepho et al. 2012), best linear unbiased estimators (BLUEs) were calculated for each trait considering genotypes as fixed and both replications and blocks nested within replications as random effects in single-environment analyses (environment $=$ P-level $\times$ location $\times$ year combination). For combined analysis within one P-level, across locations and/or locations and years, genotypes were considered fixed, while locations, years and all interactions as well as replications nested within locations and blocks nested within replications, were considered random. For combined analysis across P-levels, the genotypes and P-level treatments were considered fixed, whereas environments (location $\times$ year combination) and all interactions as well as replications nested within environments and blocks nested within replications, were considered random. In our data set, PUE had previously been shown to be highly positively correlated with grain harvest index (HI), while FLO was negatively correlated with GY (Gemenet et al. 2015a). In the present study, HI was therefore used as a fixed regression factor in the fixed model for PUE, while FLO was also used as a fixed regression factor in the fixed model for GY (Sabadin et al. 2012). Variance components were then estimated by fitting the above models with genotypes as random. Repeatability estimates $\left(w^{2}\right)$ for single-environment analysis as well as broad-sense heritability $\left(h^{2}\right)$ for combined analysis were calculated as:

$w^{2}=\sigma_{\mathrm{g}}^{2} /\left[\sigma_{\mathrm{g}}^{2}+(\mathrm{VD} / 2)\right]$

where VD is the average variance of a difference between means of genotypes and $\sigma_{\mathrm{g}}^{2}$ is the genetic variance component (Piepho and Möhring 2007).

Genetic correlations between HP and LP were calculated following Cooper et al. (1996) as:

$r_{\mathrm{g}(\mathrm{HP}, \mathrm{LP})}=r_{\mathrm{p}(\mathrm{HP}, \mathrm{LP})} /\left(w_{\mathrm{HP}}^{2} \times w_{\mathrm{LP}}^{2}\right)^{1 / 2}$

where $r_{\mathrm{p}(\mathrm{HP}, \mathrm{LP})}$ is the correlation between genotypic means under HP and LP conditions and $w_{\mathrm{HP}}^{2}$ and $w_{\mathrm{LP}}^{2}$ are the repeatability estimates (= broad-sense heritability $h^{2}$ for combined analysis) under HP and LP conditions, respectively.
Relationships between the environments were visualized using a genotype and genotype-by-environment (GGE) biplot (Yan and Kang 2002).

\section{Inference of population structure}

Population structure was examined based on the 285 DArT markers (scored as presence/absence) using a model-based approach implemented in STRUCTURE software (Pritchard et al. 2000), using the admixture model with correlated allele frequencies and without prior information. The membership of each genotype was run for the range of genetic clusters $(K)$ from $K=1$ to $K=10$ with each run consisting of 100,000 steps of burn-in followed by 100,000 replications using Monte Carlo Markov chains (MCMC) with five repetitions for each $K$. The optimal levels of likelihood $L(K)$ and the ad hoc criterion $\Delta K$ were determined from the STRUCTURE files using STRUCTURE HARVESTER (Earl and vonHoldt 2012). To avoid stochastic effects of replicated STRUCTURE runs, the results were collated using the program CLUMPP (Jakobsson and Rosenberg 2007). Furthermore, a pair-wise genetic dissimilarity matrix was calculated based on the Jaccard index implemented in DARwin 5.0.158 software (Perrier and Jacquemoud-Collet 2006). Based on the dissimilarity matrix, genotypes were assigned into clusters using the unweighted neighbor-joining method with 1000 bootstraps. A Q-matrix at $K=3$ was used in linkage disequilibrium analysis and as a covariate matrix in association analysis.

\section{Linkage disequilibrium analysis}

As we did not have information on the genetic position of most of the markers used in this study, we did not examine patterns of LD in the entire set and within-population structure subgroups but rather restricted LD analysis to markers significantly associated with traits to determine their independence. Linkage disequilibrium between marker pairs was analyzed using TASSEL 4.2.1 (Bradbury et al. 2007) and was quantified mainly based on squared correlation coefficients $\left(r^{2}\right)$ between loci. Loci were considered to be in significant $\mathrm{LD}$ when $p$ value $<0.01$. 


\section{Model selection}

We tested both general linear models (GLM) and mixed linear models (MLM) to calculate $p$ values for associating each marker with the trait of interest, along with accounting for population structure to avoid spurious associations. The population structure ( $Q$-matrix) from STRUCTURE at $K=3$ was used as a covariate to correct for population structure. The kinship matrix ( $K$-matrix) used in MLM analysis was calculated with the 285 DArT markers using TASSEL 4.2.1 (Bradbury et al. 2007). The $Q$ matrix, $K$-matrix and the phenotypic data were fitted using restricted maximum likelihood (REML) in the SAS version 9.4 mixed procedure (SAS institute 2015). In the $K$-models, we assumed that all genotypes are correlated according to the $K$-matrix and therefore this $K$-matrix was represented as a linear variance-covariance matrix in the model. In the models without $K$ ( $Q$-models), genotypes were considered independent. The denominator degrees of freedom were synthesized based on the method of Kenward and Roger (1997). Since the number of covariates required to correct for population structure varies for each trait, we tested models with $Q=1$, and $Q=2$ (as when using the $K=3 Q$ matrix, the sum of all three $Q$ values equals $100 \%$ and creates linear dependency in the analysis that can be avoided by excluding one of the $Q$ values; Ramdoss et al. 2011). The simultaneous significance of both $Q$ s in the model was tested based on an $F$ test using the SAS contrasts statement and which $Q$ was more important for each trait was compared using solutionF statement. Corrected Akaike's information criterion (AICc) computed using REML was used to compare between the $Q$ - and the $K+Q$ models. We therefore in the end had tested the following models: (1) GLM without any correction for population structure (naive model), (2) GLM with $Q$-matrix as correction for population structure ( $Q$-model), (3) MLM with kinship matrix as correction for relatedness ( $K$-model), (4) MLM with $Q$ - and $K$-matrices as correction for population structure and relatedness $(Q+K$-model, using the levels of $Q$ listed above) for each of the 38 traits presented herein. The SAS code used in model selection is given as Online Resource 3.
Association analysis and criteria for determining significant associations

A two-step association mapping (Stich et al. 2008) was applied using BLUEs from single field trials as well as from combined analyses. Association analysis was carried out based on the best identified model from the model selection step above in TASSEL 4.2.1 (Bradbury et al. 2007). The Bonferroni correction for false positives at $5 \%(0.05 /$ number of markers; maximum $p$ value $=1.8 \times 10^{-4}$ in this case) was found to be too stringent for most of the traits with this number of markers. Since population structure effects and most of the false positives had been inherently controlled by the selected associated model, a less stringent approach proposed by Chan et al. (2010) working on Arabidopsis and also applied by Pasam et al. (2012) in spring barley was considered for determining the threshold level for significant marker-trait associations. They had suggested that the bottom 0.1 percentile distribution of the $p$ values is considered as significant, which in our analysis resulted in threshold levels of $-\log (p$ values $) \geq 2$ for individual traits. Based on this and the studies by Hao et al. (2012) and Baskaran et al. (2014), we passed significant association at $-\log p>2.00, p<0.01$ threshold as a first step. This resulted in several significant associations for each trait. Since adjusting family-wise error is important in multiple testing, we additionally analyzed the $p$ values based on the false discovery rates (FDR) model proposed by Benjamini and Hochberg (1995) at $p<0.1$. We declared significant marker-trait association for markers which passed the FDR test and/or retained only the first marker with the lowest $p$ value for traits where none of the selected $p$ values passed the FDR test.

\section{Results}

Genetic variation and performance under lowphosphorus conditions

All observed and calculated traits showed large and significant genotypic variation (Table 1). Repeatability estimates $\left(w^{2}\right)$ ranged from 0.45 to 0.89 under LP and 0.56-0.91 under HP (Table 1). Repeatability 
Table 1 Best linear unbiased estimators (BLUEs; $\mu$ ) means, genetic variance components $\left(\sigma_{\mathrm{g}}^{2}\right)$ and repeatability estimates $\left(w^{2}\right)$ of traits measured under low-phosphorus (LP) and highphosphorus (HP) conditions as well as the genetic correlations $\left(r_{\mathrm{g}}\right)$ between traits measured on pearl millet inbred lines under LP and HP in six environments (site-year combinations) in West Africa

\begin{tabular}{|c|c|c|c|c|c|c|c|c|c|}
\hline \multirow[t]{2}{*}{ Year } & \multirow[t]{2}{*}{ Location } & \multirow[t]{2}{*}{ Trait } & \multicolumn{3}{|l|}{ LP } & \multicolumn{3}{|l|}{ HP } & \multirow{2}{*}{$\begin{array}{l}\mathrm{HP}, \mathrm{LP} \\
r_{\mathrm{g}}\end{array}$} \\
\hline & & & $\mu$ & $\sigma_{\mathrm{g}}^{2}$ & $w^{2}$ & $\mu$ & $\sigma_{\mathrm{g}}^{2}$ & $w^{2}$ & \\
\hline \multirow[t]{12}{*}{2011} & \multirow[t]{6}{*}{ Sadore } & PCS & 0.7 & $0.05 * * *$ & 0.74 & 0.8 & $0.05 * * *$ & 0.64 & 0.92 \\
\hline & & PCG & 2.3 & $0.04 * * *$ & 0.62 & 2.6 & $0.07 * * *$ & 0.72 & 0.95 \\
\hline & & PBM & 220.3 & $487 * * *$ & 0.60 & 254.4 & $644 * * *$ & 0.77 & 0.94 \\
\hline & & PUE & 0.3 & a $9.97 * * *$ & 0.56 & 0.2 & a $8.53 * * *$ & 0.62 & 0.99 \\
\hline & & FLO & 65.6 & $20.5 * * *$ & 0.89 & 61.3 & $15.7 * * *$ & 0.88 & 0.98 \\
\hline & & GY & 62.6 & $528 * * *$ & 0.57 & 67.0 & $783 * * *$ & 0.71 & 0.85 \\
\hline & \multirow[t]{2}{*}{ Koporo } & FLO & 72.6 & $22.4 * * *$ & 0.84 & 71.1 & $20.0 * * *$ & 0.81 & 0.98 \\
\hline & & GY & 79.5 & $939 * * *$ & 0.59 & 87.1 & $1184 * * *$ & 0.60 & 0.97 \\
\hline & \multirow[t]{2}{*}{ Gampela } & FLO & 66.5 & $17.1 * * *$ & 0.77 & 64.5 & $11.5 * * *$ & 0.84 & 0.90 \\
\hline & & GY & 65.1 & $609 * * *$ & 0.52 & 91.8 & $1062 * * *$ & 0.66 & 0.53 \\
\hline & \multirow[t]{2}{*}{ Bambey } & FLO & 64.5 & $34.2 * * *$ & 0.73 & 61.4 & $33.8 * * *$ & 0.79 & 0.91 \\
\hline & & GY & 60.7 & $1178 * * *$ & 0.71 & 69.9 & $1911 * * *$ & 0.72 & 0.99 \\
\hline \multirow[t]{4}{*}{2012} & \multirow[t]{2}{*}{ Sadore } & FLO & 68.2 & $42.7 * * *$ & 0.78 & 61.5 & $19.3 * * *$ & 0.84 & 0.73 \\
\hline & & GY & 23.2 & $173.3 * * *$ & 0.45 & 36.2 & $330.1 * * *$ & 0.56 & 0.80 \\
\hline & \multirow[t]{2}{*}{ Gampela } & FLO & 66.6 & $19.8 * * *$ & 0.74 & 63.2 & $15.2 * * *$ & 0.91 & 0.84 \\
\hline & & GY & 53.6 & $298 * * *$ & 0.57 & 68.2 & $747 * * *$ & 0.58 & 0.77 \\
\hline
\end{tabular}

$\mathrm{PCS}=\mathrm{P}$ concentration in stover $\left(\mathrm{mg} \mathrm{g}^{-1}\right), \mathrm{PCG}=\mathrm{P}$ concentration in grain $\left(\mathrm{mg} \mathrm{g}^{-1}\right), \mathrm{PBM}=\mathrm{P}$ in total biomass $(\mathrm{P}$ uptake; $\left.\mathrm{mg} \mathrm{m}^{-2}\right)$, PUE $=$ P-utilization efficiency corrected for harvest index $\left(\mathrm{g} \mathrm{mg}^{-1} \mathrm{P}\right)$, FLO = days to flowering (days), GY $=$ grain yield $\left(\mathrm{g} \mathrm{m}^{-2}\right)$

*** Significant at $p<0.001$

a Variance component multiplied by 10,000 for easy readability

estimates were in most cases reduced under LP cf. HP. Except for FLO and PUE, which had higher means under LP, most traits had reduced means under LP although the differences between the means were not very large between the HP and LP treatments in a given site $\times$ year pair of environments (Table 1 ). Genetic correlations between performance under HP and under LP were consistently high, ranging from 0.53 to 0.99 (Table 1). For combined analysis across locations within one P-level, broad-sense heritability $\left(h^{2}\right)$ was 0.67 under LP and 0.76 under HP for GY and 0.93 under LP and 0.94 under HP for FLO (Online Resource 4). For combined analysis across P-levels, broad-sense heritability $\left(h^{2}\right)$ was 0.81 and 0.97 for GY and FLO, respectively (Online resource 4). Variance components for different sources of variance in the combined analyses for GY are provided in detail in Gemenet et al. (2014). The ratio of the genotypic variance component to that of genotype-by-P-level interaction $(\mathrm{G}: \mathrm{G} \times \mathrm{P})$ was 1:0.05, whereas the genotypic variance component ratio to that of genotype-by-environment $(\mathrm{G}: \mathrm{G} \times \mathrm{E}$; environment $=$ location $\times$ year combination) was 1:0.52 (Gemenet et al. 2014). The GGE biplot shows that most environments were not very differentiated in the current study as all environments appear in two very close sectors except Bambey 2011, which was clearly separated from the other environments (Online Resource 5). No mega-environments were observed for P-levels in the GGE biplot (Online Resource 5).

Population structure

STRUCTURE results indicated a maximum $\Delta K$ at $K=3$ (Online Resource 6) indicating three subgroups among the 155 genotypes. Assignment at $>0.8$ probability based on the collated $K=3$ clustering could apportion $31.8 \%$ of the inbred lines to subgroups, $>0.7$ could apportion $47.3 \%$ inbred lines to subgroups, and $>0.6$ could assign $68.9 \%$ inbred lines to 
subgroups. These three subgroups were also observed from the unweighted neighbor-joining tree as three major groups each with its own subgroups (Fig. 1). These three major subgroups appear to have been grouped mainly based on flowering time because Q1 was negatively correlated with time to $50 \%$ flowering (FLO; $r=0.44$ ), and Q2 was positively correlated with FLO $(r=0.40)$, while Q3 did not show significant correlation with FLO (data not shown).

Associations between phenotypes and genotypes

\section{Model selection}

Several models were compared to assess their usefulness in accounting for population structure and their ability to reduce the inflation of false positive associations (Type I error). The AICc values for the $K+Q$ - and the $Q$-models, together with the selected model and the number of $Q$ s required to control for population structure, if any, are shown in Online Resource 7. In most cases, controlling for population structure was sufficient for most flowering time traits while controlling for relatedness rather than population structure was more appropriate for grain yield traits. The model comparison step is also graphically presented for combined GY across environments (location $\times$ year combination) and P-levels (GY_HLP_Com), which is one of the 38 traits analyzed in the current study in Online Resource 8, where ranked $p$ values for each model were cumulatively plotted. It can be observed that the naive model performed similarly to both of the $Q$-models. The $K$ model and the two $Q+K$-models also performed
Fig. 1 Unweighted neighbor-joining tree based on dissimilarities in 151 pearl millet inbred lines from WA using 285 DArT markers. The colors represent the three main subgroups. Scale (0-0.1) indicates genetic distance. The numbers correspond to the inbred line numbers which are indicated by the last three digits of the inbred line names as presented in Online Resource 1. (Color figure online)

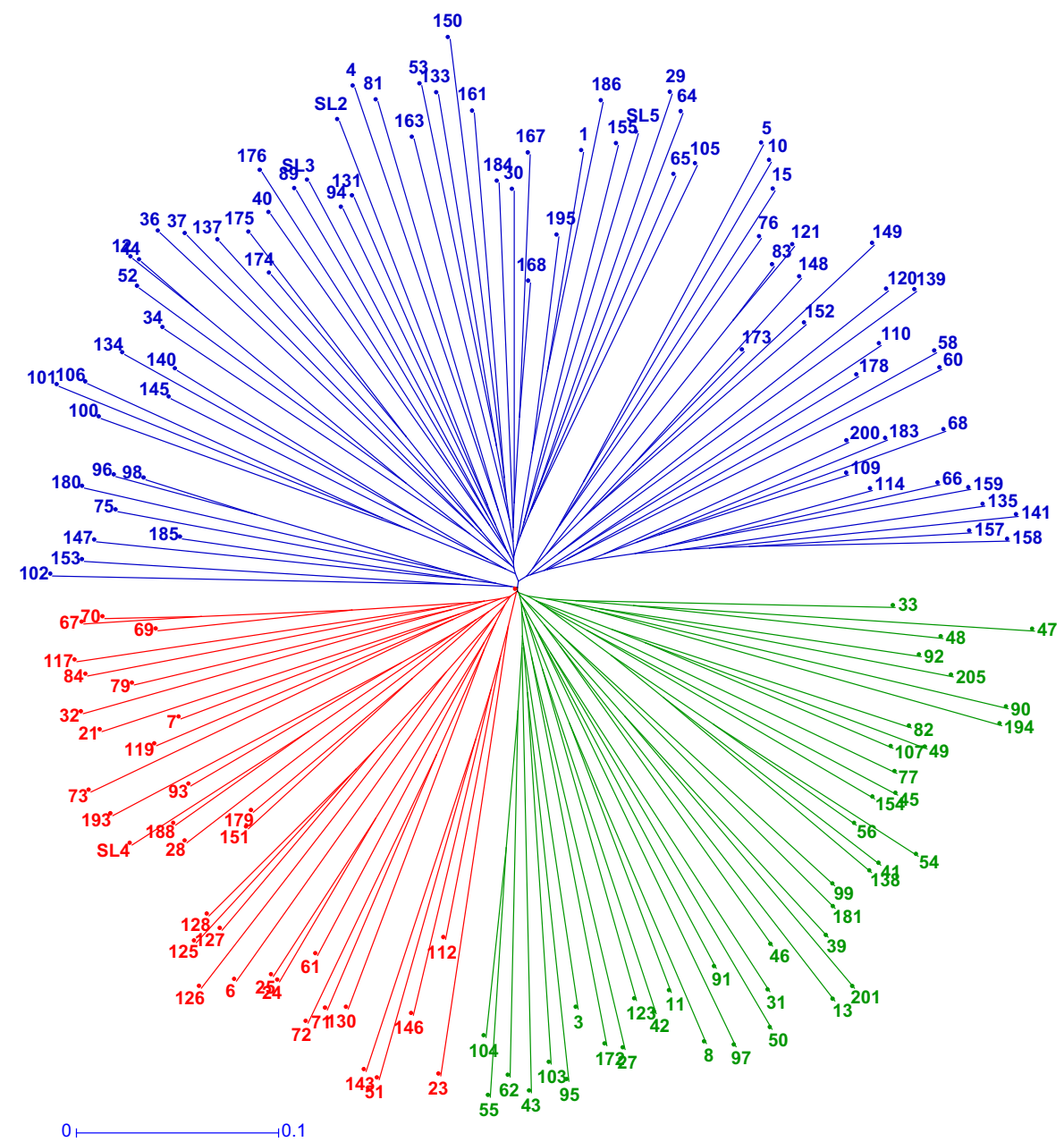


similarly (Online Resource 8), and being a grain yield trait, it can be seen that controlling for relatedness was more desirable. There was a low level of relatedness in the inbred lines as can be seen in the kinship heat map presented as Online Resource 9.

\section{Marker-trait associations for phosphorus-efficiency- related traits}

Nine markers were found to be significantly associated with the four P-efficiency-related traits (Table 2). The markers individually explained about $7-16 \%$ of the observed variance in the respective traits (Table 2). One marker each was significantly associated with reduction in PCG under HP and LP. Two markers were significantly associated with increased PCS under HP, while one marker was associated with reduced PCS under LP. Three markers, one of which was associated with increased PBM, while two were associated with reduction in PBM, were found significant under HP, while one marker associated with reduced PBM was significant under LP. One marker each under HP and LP was significantly associated with reduced PUE. Marker $P g P b 7101$ was significantly associated with

Table 2 Markers significantly associated with phosphorus (P) efficiency-related traits: $\mathrm{P}$ concentration in grain (PCG; $\mathrm{mg} \mathrm{g}^{-1}$ ), $\mathrm{P}$ concentration in stover (PCS; $\mathrm{mg} \mathrm{g}^{-1}$ ), P-uptake efficiency ( $\mathrm{P}$ in total biomass; $\mathrm{PBM} ; \mathrm{mg} \mathrm{m}^{-2}$ ) and P-utilization efficiency (PUE; $\mathrm{g} \mathrm{mg}^{-1} \mathrm{P}$ ) measured in pearl millet inbred lines under low-phosphorus (LP) and high-phosphorus (HP) conditions at Sadore (Niger) in 2011, their $p$ values, the percentage of variance explained by the association and the estimated marker effects

\begin{tabular}{lllcr}
\hline Trait & Marker & $p$ value & $\%$ variance & Effect $^{\mathrm{a}}$ \\
\hline PCG_HP & PgPb12598 & $6.7 \times 10^{-3}$ & 6.9 & -0.13 \\
PCG_LP & PgPb12839 & $3.3 \times 10^{-3}$ & 8.6 & -0.20 \\
PCS_HP & PgPb7101 & $8.5 \times 10^{-6}$ & 15.9 & 0.74 \\
& PgPb8535 & $9.6 \times 10^{-4}$ & 9.1 & 0.21 \\
PCS_LP & PgPb8177 & $7.7 \times 10^{-4}$ & 8.4 & -0.25 \\
PBM_HP & PgPb7101 & $4.2 \times 10^{-5}$ & 14.4 & 68.0 \\
& PgPb11170 & $4.6 \times 10^{-5}$ & 14.3 & -12.1 \\
& PgPb8935 & $3.7 \times 10^{-4}$ & 11.1 & -20.4 \\
PBM_LP & PgPb7983 & $6.8 \times 10^{-4}$ & 10.2 & 34.0 \\
PUE_HP & PgPb7101 & $1.0 \times 10^{-4}$ & 11.2 & -0.01 \\
PUE_LP & PgPb13376 & $6.4 \times 10^{-3}$ & 6.9 & -0.03 \\
\hline
\end{tabular}

\footnotetext{
${ }^{a}$ Marker effects refer to presence of the marker
}

three of the four P-efficiency-related traits under HP, being significantly associated with increased PCS, increased PBM and reduced PUE (Table 2).

\section{Marker-trait associations for days to flowering}

A total of nine markers were found to be significantly associated with FLO (Table 3), each individually explaining about 5.5-9.9\% of the observed variation for flowering time. Four of these markers were found significantly associated with FLO in only one environment, while the remaining five were found significantly associated with FLO in more than one environment. The markers with significant association with FLO in more than one environment are highlighted in bold in Table 3. Marker PgPb11603 appeared to be the most stable as it was found significant in Sadore in both 2011 and 2012 and was also the marker significantly associated with combined effects for FLO under both HP and LP. Most markers did not show specificity for either HP or LP (Table 3).

\section{Marker-trait associations with grain yield}

A total of 13 markers individually explaining about $7.2-15.6 \%$ of the observed variation were found to be significantly associated with GY (Table 4). Ten of these markers were significantly associated with GY in only a single environment, while the remaining three:

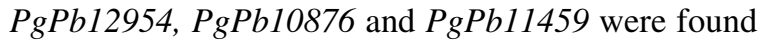
to be significantly associated with GY in more than one environment and/or combined effects. Marker $\mathrm{PgPb} 12954$ had the most stable associations with increased GY of between 10.0 and $21.0 \mathrm{~g} \mathrm{~m}^{-2}$ (Table 4).

\section{Colocation of markers for different traits}

Two markers were found to be significantly associated with more than one trait. Marker $P g P b 6780$, which was significantly associated with reduced FLO in Gampela and Sadore in 2011 (Table 3), was also associated with increased GY in Gampela 2011 (Table 4), whereas marker $\mathrm{PgPb7101}$, which was found significantly associated with increased PCS, increased PBM and reduced PUE, was also associated with increased GY in Gampela 2011. 
Table 3 Markers significantly associated with days to flowering (FLO; days) measured on pearl millet inbred lines under highphosphorus (HP) and low-phosphorus (LP) conditions (P-level) in six environments (site-year combinations) in West Africa, their $p$ values, the percentage of variance explained by the associations and the estimated marker effects

\begin{tabular}{|c|c|c|c|c|c|c|}
\hline Year & Location & P-level & Marker & $p$ value & $\%$ variance & Effect $^{\mathrm{a}}$ \\
\hline \multirow[t]{10}{*}{2011} & \multirow[t]{2}{*}{ Bambey } & HP & PgPb5985 & $2.1 \times 10^{-3}$ & 7.0 & -1.5 \\
\hline & & LP & PgPb6723 & $4.9 \times 10^{-4}$ & 7.7 & 1.9 \\
\hline & \multirow[t]{2}{*}{ Gampela } & HP & PgPb6780 & $6.7 \times 10^{-4}$ & 9.9 & -4.5 \\
\hline & & LP & $\mathrm{PgPb} 6798$ & $1.5 \times 10^{-3}$ & 8.4 & -1.4 \\
\hline & \multirow[t]{3}{*}{ Koporo } & \multirow[t]{2}{*}{ HP } & PgPb5985 & $2.5 \times 10^{-4}$ & 7.8 & -1.7 \\
\hline & & & PgPb6723 & $9.7 \times 10^{-4}$ & 6.6 & 1.6 \\
\hline & & LP & PgPb5985 & $2.3 \times 10^{-4}$ & 8.2 & -2.1 \\
\hline & \multirow[t]{3}{*}{ Sadore } & \multirow[t]{2}{*}{ HP } & PgPb6780 & $1.5 \times 10^{-3}$ & 6.3 & -3.8 \\
\hline & & & PgPb11603 & $1.8 \times 10^{-3}$ & 6.1 & -1.7 \\
\hline & & LP & PgPb10709 & $4.0 \times 10^{-4}$ & 5.5 & 0.6 \\
\hline \multirow[t]{5}{*}{2012} & \multirow[t]{2}{*}{ Gampela } & HP & $\mathrm{PgPb} 12084$ & $3.2 \times 10^{-4}$ & 9.0 & -2.1 \\
\hline & & LP & PgPb12472 & $2.6 \times 10^{-3}$ & 7.3 & -4.3 \\
\hline & \multirow[t]{3}{*}{ Sadore } & HP & PgPb11603 & $1.8 \times 10^{-3}$ & 8.6 & -2.4 \\
\hline & & & $\mathrm{PgPb} 12306$ & $1.9 \times 10^{-4}$ & 8.4 & -3.6 \\
\hline & & LP & PgPb11603 & $1.9 \times 10^{-3}$ & 7.7 & -1.0 \\
\hline \multirow[t]{4}{*}{ Combined } & \multirow[t]{4}{*}{ Across } & HP & PgPb11603 & $7.8 \times 10^{-4}$ & 6.9 & -2.0 \\
\hline & & LP & PgPb11603 & $2.0 \times 10^{-3}$ & 6.1 & -1.6 \\
\hline & & \multirow[t]{2}{*}{ HP and LP } & PgPb11603 & $8.9 \times 10^{-4}$ & 6.8 & -1.8 \\
\hline & & & PgPb12472 & $2.3 \times 10^{-3}$ & 5.9 & -2.9 \\
\hline
\end{tabular}

${ }^{a}$ Marker effects refer to the presence of the marker

Bold indicates the probability of marker-trait association

\section{Linkage disequilibrium between markers}

A few of the markers reported to have significant associations with various traits related to performance under contrasting P-levels as reported were found to be in significant LD $p<0.01$. Marker $P g P b 10709$ found to be associated with increased FLO by about 0.6 days was in significant LD with marker $P g P b 12472$ (Table 3), which was also associated with reduced FLO, and marker $\mathrm{PgPb11459}$, which was associated with reduced GY (Table 4). Marker $\mathrm{PgPb} 11459$ was also in significant LD with marker $\mathrm{PgPb10217}$, which was also associated with reduced GY (Table 4). Marker PgPb7461 significantly associated with reduced GY in Bambey 2011 was in significant LD with marker $P g P b 6628$ associated with increased GY in Sadore 2011 and marker $P g P b 7101$ (Table 4) significantly associated with increased GY in Gampela 2011. Markers $\mathrm{PgPb} 7983$ and $\mathrm{PgPb} 1170$ (Table 2) both associated with PBM were also in significant LD.

\section{Discussion}

Low level of differentiation between P-levels in field evaluation

Low-P conditions have been reported to lead to reduced GY and delayed FLO in sorghum, (Leiser et al. 2012), maize (Parentoni et al. 2010) and common bean (Beebe et al. 2007). Although we observed delayed FLO and reduced GY across all environments under LP conditions, as well reduced means for PCG, PCS and PBM under LP; the observed differences between the P-levels were not very large, and the genetic correlation values between HP and LP were high (indicative of pearl millet's relatively good tolerance to the low-P conditions used in these trials). This can also be observed in the GGE plot where the angle between HP and LP was always small with no mega-environments observed for P-levels in all environments (site $\times$ year combinations) and implies that both of our P-levels rank the 155 pearl millet inbred 
Table 4 Markers significantly associated with grain yield (GY; $\mathrm{g} \mathrm{m}^{-2}$ ) measured on pearl millet inbred lines under highphosphorus (HP) and low-phosphorus (LP) conditions (P-level) across six environments (site-year combinations) in West Africa, their $p$ values, the percentage of variance explained by the associations and the estimated marker effects

\begin{tabular}{|c|c|c|c|c|c|c|}
\hline Year & Location & P-level & Marker & $p$ value & $\%$ variance & Effect $^{\mathrm{a}}$ \\
\hline \multirow[t]{10}{*}{2011} & \multirow[t]{2}{*}{ Bambey } & $\mathrm{HP}$ & $\mathrm{PgPb} 7461$ & $7.5 \times 10^{-4}$ & 8.8 & -34.8 \\
\hline & & LP & PgPb12954 & $1.6 \times 10^{-3}$ & 8.8 & 21.0 \\
\hline & \multirow[t]{2}{*}{ Gampela } & HP & $\mathrm{PgPb} 6780$ & $2.8 \times 10^{-3}$ & 8.2 & 16.5 \\
\hline & & LP & $\mathrm{PgPb} 7101$ & $4.0 \times 10^{-3}$ & 7.2 & 17.9 \\
\hline & \multirow[t]{4}{*}{ Koporo } & \multirow[t]{2}{*}{$\mathrm{HP}$} & $\mathrm{PgPb} 10674$ & $4.8 \times 10^{-5}$ & 14.2 & 47.1 \\
\hline & & & PgPb12954 & $1.1 \times 10^{-3}$ & 9.5 & 16.0 \\
\hline & & \multirow[t]{2}{*}{ LP } & PgPb10876 & $8.2 \times 10^{-4}$ & 10.0 & 20.4 \\
\hline & & & PgPb12954 & $1.1 \times 10^{-3}$ & 9.5 & 15.8 \\
\hline & \multirow[t]{2}{*}{ Sadore } & $\mathrm{HP}$ & $\mathrm{PgPb} 6628$ & $2.9 \times 10^{-3}$ & 8.1 & 20.4 \\
\hline & & LP & $\mathrm{PgPb} 11235$ & $5.7 \times 10^{-4}$ & 10.5 & 12.2 \\
\hline \multirow[t]{6}{*}{2012} & \multirow[t]{3}{*}{ Gampela } & \multirow[t]{2}{*}{$\mathrm{HP}$} & PgPb12954 & $4.9 \times 10^{-4}$ & 10.7 & 10.3 \\
\hline & & & $\mathrm{PgPb} 11056$ & $4.9 \times 10^{-4}$ & 10.7 & 13.3 \\
\hline & & LP & PgPb9967 & $1.9 \times 10^{-3}$ & 8.8 & 0.6 \\
\hline & \multirow[t]{3}{*}{ Sadore } & $\mathrm{HP}$ & $\mathrm{PgPb} 10217$ & $6.1 \times 10^{-4}$ & 9.6 & -4.6 \\
\hline & & LP & PgPb10876 & $2.5 \times 10^{-5}$ & 15.6 & 26.1 \\
\hline & & & $\mathrm{PgPb} 10468$ & $2.1 \times 10^{-4}$ & 12.3 & 31.1 \\
\hline \multirow[t]{7}{*}{ Combined } & \multirow[t]{7}{*}{ Across } & \multirow[t]{2}{*}{$\mathrm{HP}$} & PgPb12954 & $2.3 \times 10^{-4}$ & 11.8 & 10.3 \\
\hline & & & PgPb11459 & $1.0 \times 10^{-3}$ & 9.6 & -21.7 \\
\hline & & \multirow[t]{2}{*}{ LP } & PgPb12954 & $1.2 \times 10^{-4}$ & 12.8 & 11.0 \\
\hline & & & PgPb10876 & $8.8 \times 10^{-4}$ & 9.8 & 17.6 \\
\hline & & \multirow[t]{3}{*}{ HP and LP } & PgPb12954 & $1.1 \times 10^{-4}$ & 12.9 & 10.0 \\
\hline & & & PgPb10876 & $9.5 \times 10^{-4}$ & 9.7 & 21.0 \\
\hline & & & PgPb11459 & $1.8 \times 10^{-3}$ & 8.8 & -18.4 \\
\hline
\end{tabular}

\footnotetext{
${ }^{a}$ Marker effects refer to the presence of the marker
}

Bold indicates the probability of marker-trait association

genotypes in a similar manner. In Gemenet et al. (2014), we reported small relative yield reductions across locations with a mean of $23.5 \%$ in the combined analysis. This occurred despite our adding a substantial amount of $\mathrm{P}$ to the HP treatment and implies that the $\mathrm{P}$ effect was masked (at least partially) in these experiments. According to Valluru et al. (2010), early season P-deficiency results in early irreversible growth restriction in pearl millet. Year 2011 was a major drought year within the study region (Haesler 2012), and drought occurring early in the rainy season led to delay of fertilizer application by as much as $>2$ weeks (to avoid fertilizer-induced burning of seedlings due to inadequate soil moisture). This could largely explain the lack of a strong P effect in the evaluations conducted in 2011 (and across the 2011 and 2012 rainy seasons). However, this was not the only reason for the small observed effect of P-levels in this study as in 2012 there was enough rainfall at sowing time, the fertilizer treatments were applied at the time of sowing, and the amount of $\mathrm{P}$ was doubled, but still no strong P effect was observed. This implies that besides late P-application in 2011, other soilrelated factors were in play. It has long been pointed out that in environments that are less favorable for agricultural production such as those of the West African Sahel, moisture and soil toxicity constraints interact very strongly with soil nutrient availability to the extent that it even becomes difficult to obtain economic responses to individual fertilizers and/or other soil amendments (Brück et al. 2000; Payne et al. 1995; Schaffert et al. 2000; Zaongo et al. 1994; Subbarao et al. 2000; Hash et al. 2002) except compost or farmyard manure. Aluminum $(\mathrm{Al})$ toxicity and $\mathrm{P}$ 
fixation due to mineral compositions high in iron $(\mathrm{Fe})$ and $\mathrm{Al}$ oxides are common in tropical acid soil savannas including the WA Sahel (Schaffert et al. 2000; Weir 1972, 1977; Hash et al. 2002). Despite these limitations, we observed high enough repeatability estimates (and broad-sense heritabilities for combined analyses) with substantial genetic variation for all directly observed and calculated traits, and these data could therefore be used in further analysis.

Subtle population structure and familial relatedness in the study panel

Populations used in association studies are classified into five groups as (1) ideal samples with subtle population structure and little-if-any familial relatedness, (2) multi-family samples, (3) samples with population structure, (4) samples with both population structure and familial relationships and (5) samples with severe population structure and familial relationships (Yu and Buckler 2006; Yu et al. 2006; Zhu et al. 2008). In the current study, we observed three population structure subgroups, mainly based on FLO. This is expected because flowering time has been shown to be a major adaptive trait in crop plants such as maize and pearl millet (Camus-Kulandaivelu et al. 2006; Stich et al. 2010). Studies on pearl millet diversity in WA have not reported any substantial differentiation of pearl millet based on geographic distance or agroecological zones (Tostain et al. 1987; Oumar et al. 2008; Stich et al. 2010). Genetic diversity based on simple sequence repeat markers in the current West African pearl millet inbred germplasm association panel (WA-PMiGAP) is reported in detail by Stich et al. (2010). According to Pucher et al. 2015, flowering time is differentiated in pearl millet based on latitude with varieties toward the north being more earlier flowering compared with varieties preferred for the south. This could also be the reason why in the present study controlling for population structure and not so much of kinship was important for FLO. The presence of strong population structure may result in Type I error if not accounted for (Zhu et al. 2008). Whereas several statistical models have been proposed to account for population structure in association analysis (Yu et al. 2006; Zhao et al. 2007), there is need for balancing the rates of false positives and false negatives (Pasam et al. 2012), so several of these models were tested in the present study. It is evident from the present study that the observed population structure within WA-PMiGAP was not very strong as the Q-model and naive model performed almost similarly in accounting for population structure (see Online Resource 8). Familial relatedness was also low as can be observed from the kinship matrix provided as Online Resource 9. Baskaran et al. (2009) similarly observed few differences between marker-trait associations detected using a naive model and one including population structure, in a pearl millet study involving five sets of full-sib progenies generated from populations along a chain of five random-mating populations starting with a new base population derived from a population cross made at ICRISAT, Patancheru, and an improved open-pollinated variety derived from that population which was developed, tested and released for cultivation in Tamil Nadu state in southern India. In that case, the random-mated base population and its four sequentially derived populations were each based on a recombination of at least 50 full-sib progenies and hence expected to be in nearly complete linkage disequilibrium. As subsequently demonstrated (Baskaran et al. 2014), this means that use of codominant markers with highly heterozygous full-sib progeny sets developed from a truly randommating population can be very effective for detection of marker-trait associations-even without taking into account population structure, as population structure accounts for less than $1 \%$ of the observed genetic variance in such cases. This in turn means that markerassisted population improvement (MAPI) using fullsib progenies can be expected to be very efficientand directly applicable for improvement of highly heterozygous open-pollinated varieties of seed-propagated crops or clonally propagated crops. Applied marker-assisted selection is not just for those selfpollinated crop species (or cross-pollinated species where inbreeding is practical), where marker-assisted pedigree selection is practical. It also has tremendous potential for use in applied improvement of allogamous species (crops, livestock, etc.).

\section{Significant marker-trait associations}

Several statistically significant putative marker-trait associations were identified for P-related traits, FLO and GY. Most markers involved in these putative markertrait associations were not in significant LD with each other implying that they segregate independently. 


\section{Low-P tolerance-related traits}

Here, we present the first report of association mapping for low-P tolerance-related traits in pearl millet. Significant marker-trait associations were observed for PCG, PCS, PBM and PUE. QTLs associated with low-P tolerance traits have been reported previously in several crops such as rice (Wissuwa et al. 2002), wheat (Su et al. 2009), common bean (Beebe et al. 2006), soybean (Zhang et al. 2009; King et al. 2013), barley (Gahoonia and Nielsen 2004), maize (Chen et al. 2009, 2011) and sorghum (Hufnagel et al. 2014). Most of these studies examined $P$ efficiency in early plant growth stages, for which applied utility as a secondary trait in plant breeding is dependent upon both secondary trait heritability and its correlation with GY (Gemenet et al. 2015a). Few previous studies have examined these traits at maturity under field conditions. Mendes et al. (2014) identified six QTLs associated with P-uptake efficiency and five QTLs associated with P-utilization efficiency in maize under field conditions. The current findings therefore offer new insights for breeding programs aiming to improve $\mathrm{P}$ efficiency in pearl millet. To be useful in marker-assisted selection programs targeting low-P environments, the putative marker-trait associations identified in this study need to be validated either (1) across environments and in different genetic backgrounds or (2) more quickly and less expensively (at least for pearl millet) by direct selection for and against specific marker alleles within the WAPMiGAP, recombination of replicated selected subsets of this inbred panel (that is, groups of inbreds that either have or do not have the specific presence/ absence marker of interest for a given target trait), and replicated field testing of the replicated recombined pairs of subpopulations under HP and LP conditions. Such validation is required as the P-efficiency-related traits in this study were measured in only one location (but several environments), and some evidence of the desired response to selection is necessary before more routine use of these DArT markers (or others found to be genetically linked to them) can be recommended.

\section{Days to flowering and grain yield}

Our strategy to detect marker-trait associations for FLO and GY measured in different locations and years attempted to identify every possible marker-trait association in each testing environment, as well as capturing those markers with effects detected in multiple environments. Most markers significantly associated with these traits did not show specificity for either HP or LP. This is probably because of the lack of a strong response to $\mathrm{P}$ fertilization (i.e., $\mathrm{P}$ effect) in our field trials (Gemenet et al. 2014), which implies that plant growth in both P-levels may have been limited by some other factor (perhaps the P-fixation capacity of the Fe- and Al-rich soils on which the field experiments were conducted).

We found several significant associations for FLO with some markers exhibiting stable associations with this trait across environments, while others detected associations that were specific for single environments. Being a major adaptive trait in pearl millet, genomic regions contributing to variations in FLO have been shown to be present in all seven linkage groups of pearl millet (Hash et al. 1995, 2003; Yadav et al. 2002, 2003). Clotault et al. (2012) and Lakis et al. (2012) suggested that the wide variation in FLO in pearl millet is likely to be under the influence of several genes. A majority of the presence/absencescored DArT marker involved in associations with FLO that were identified in the current study were associated with early flowering - the only explanation for this is chance, as a representative random sample of such marker-trait associations would be expected to have about half showing negative additive effects and the other half showing positive additive effects. Saidou et al. (2009, 2014) showed that the region around the PHYTOCHROME C (PHYC) gene is responsible for FLO variation in pearl millet and identified an early-flowering allele within the PHYC region. Similarly, two independently segregating, recessively inherited genes, $e_{1}$ and $e_{2}$, were previously shown to confer photoperiod-insensitive early flowering in pearl millet (Anand Kumar and Andrews 1993), and many other relatively early-maturing pearl millets exhibit dominant or partially dominant early flowering that is very useful in breeding early-maturing hybrids (e.g., A/B-pairs 834A/B, 842A/B, 843A/B, 863A/B and ICMA/B 88004, all of which appear to have an early-maturing, bold-seeded, agronomically elite Iniari landrace-based parentage (Andrews and Kumar 1996; Stegmeier et al. 1998a, b; Rai et al. 1995, 2008). Due to the current lack of information concerning map positions of most of the markers identified to be significantly associated with FLO in the current study, 
it is not possible yet to compare them with previously reported QTLs and/or genes associated with flowering time in pearl millet.

Future sequencing of the DArT clones upon which these markers are based, combined with pending release of the aligned pearl millet genome sequence, will soon permit us to overcome this minor academic inconvenience.

Several DArT markers showed significant associations with GY, having effects in single environments and/or in multiple environments. This is the first study to examine GY performance under LP conditions in pearl millet in replicated field trials. The main reason for capturing both specific- and multiple-effect marker-trait associations in the current study is that both FLO and GY are complex traits exhibiting strong $\mathrm{G} \times \mathrm{E}$ interaction (Kraakman et al. 2004), with specific flowering alleles in specific genomic regions being more favorable in some environments and less favorable in other environments (e.g., Yadav et al. 2003); hence, selection for appropriate flowering time in the target environment itself, or in an artificially manipulated photoperiod-temperature regime that mimics the target environment, is required for conventional breeding approaches to get flowering time 'right.' As flowering time is among the most highly heritable of traits when the physical environment (moisture, temperature, light and nutrient availability) is favorable, this is relatively easily accomplished for favorable crop production environments. However, in more challenging environments, such as those represented by the narrow bands of mean annual precipitation isohyets across inland WA, selection for the desirable photoperiod-temperature response is already a challenge for conventional breeding programs-even before bringing the possible role of nutrient deficiencies or pest-induced delays in effective flowering time into consideration. It is expected that better information about allele-specific associations of numerous marker loci distributed across the entire nuclear genome will soon make it possible to achieve this without the several years of multiple sowing-date observations that are currently required to get the most favorable photoperiod-temperature response of flowering in crop varieties targeted for environments where this is an essential component of local adaptation.

Despite the low differentiation among most of our evaluation environments, as observed from the GGE plot, we identified both stable and environmentspecific marker-trait associations with each location showing at least one specific marker-trait association for FLO and/or GY. According to Collins et al. (2008), QTLs can be categorized as being either constitutive (consistently identified across most environments) or adaptive (detected only in specific environmental conditions). We can therefore classify the associations of $\mathrm{PgPb11603}$ with FLO and $\mathrm{PgPb} 12954$ with GY, which were more stable across environments, as being associated with constitutive QTLs, while most of putative marker-trait associations identified for these two traits in the present study can be considered as being associated with adaptive QTLs. Two propositions are available to explain genetic control of trait stability in multiple environments: (1) where the constitutive gene is itself regulated in direct response to the environment, referred to as the allele-sensitivity model, or (2) where regulatory loci are under the direct influence of the environment and they in turn switch on and off the constitutive genes (Via et al. 1995). More progress in QTL mapping and association analysis for GY in pearl millet has been achieved under terminal drought stress with a major QTL being identified and validated on linkage group 2 (Yadav et al. 2002, 2003, 2004, 2011; Bidinger et al. 2005, 2007; Serraj et al. 2005; Sehgal et al. 2012), for which improved terminal drought tolerance (Kholová et al. 2010a, b) and salinity tolerance (Sharma et al. 2014) appear to be associated with constitutively elevated foliar ABA levels. In contrast, not much information is available on genetic variation in pearl millet GY performance under P-limited conditions. Genomic regions responsible for GY performance under P-limited conditions have been recently reported in sorghum (Leiser et al. 2014; Hufnagel et al. 2014) and maize (Mendes et al. 2014). The findings from the current study therefore will contribute toward bridging the gap between quantitative and molecular methods of studying complex traits like low-P tolerance in West Africa.

\section{Pleiotropy versus close linkage}

An interesting contribution of marker-trait association analysis is the possibility of elucidating the genetic basis of associated traits (Tuberosa et al. 2002). The colocation of QTLs for different traits implies the likely presence of pleiotropy or tight linkage between 
the QTLs that control the trait (Lebreton et al. 1995; Gemenet et al. 2010; Baskaran et al. 2014). In our case, marker $\mathrm{PgPb} 7101$ had significant association with PCS, PBM and PUE. The negative effect of this marker on PUE together with its positive effect on PBM could just be a reflection of the confounding effects of $\mathrm{P}$ uptake on P-utilization efficiency. Rose et al. (2010) suggested that plants with a higher $P$ uptake suffer less from low-P stress and would not show much P-utilization efficiency. This marker was also observed to be associated with increased grain yield in one environment. Several studies have reported colocation of QTLs for P uptake (PBM in this case) and GY in different crops implying the possibility that the two traits are likely to be influenced by same genomic regions. Hufnagel et al. (2014) recently reported that the same genomic region was responsible for $\mathrm{P}$ uptake and GY performance under LP conditions in sorghum. As we are dealing with the presence/absence type of markers, whose map positions mostly are unknown, it is not possible to tell with these preliminary findings whether the associations between the two traits in our case are driven by the same molecular polymorphism or by different polymorphisms closely linked (Saidou et al. 2014). Validation of the current putative marker-trait associations is therefore necessary.

\section{Conclusions}

We report here the first findings on marker-trait associations for pearl millet under low-P conditions in WA. We observed a subtle population structure and limited familial relatedness, in the germplasm association panel of inbred lines derived from West African landraces and improved open-pollinated varieties (WA-PMiGAP) used in this study. We identified several markers associated with P-efficiency-related traits, time to flowering and/or grain yield. There is a possibility that genomic regions responsible for P-efficiency and GY are colocalized in pearl millet. There is, however, need to further validate the marker-trait associations identified here.

Acknowledgments The financial support from the German Federal Ministry for Economic Cooperation and Development (BMZ) through the BMZ-Abiotic Stress project (GIZ Project Number 09.7860.1-001.00) based at ICRISAT West AfricaNiamey, from Foundation 'Fiat Panis' through the Food
Security Centre at University of Hohenheim to DC Gemenet and from the McKnight Foundation Collaborative Crop Research Program to BIG Haussmann is gratefully appreciated. We thank Mr. Hamadou Adamou, Mr. Ada Abarchi and Mr. Issa Karimou (all at ISC-Sadoré) for preparing and coordinating the field trials within the region. Our sincere appreciation is extended to the technical staff at collaborating NARs in Burkina Faso, Mali and Senegal for conducting trials in their respective countries. The publication is an output of a scholarship from the Food Security Centre from the University of Hohenheim, which is part of the DAAD (German Academic Exchange Service) program 'exceed' and is supported by DAAD and BMZ. The work was finalized as part of the CGIAR Research Program on Dryland Cereals.

\section{References}

Anand Kumar K, Andrews DJ (1993) Genetics of quantitative traits in pearl millet: an overview. Crop Sci 33:1-20

Andrews DJ, Kumar KA (1992) Pearl millet for food, feed and forage. Adv Agron 48:89-139

Andrews DJ, Kumar KA (1996) Use of the West African pearl millet landrace Iniadi in cultivar development. Plant Genet Resour Newsl 105:15-22

Bashir EMA, Abdelbagi MA, Adam MA, Melchinger AE, Parzies HK, Haussmann BIG (2014a) Characterization of Sudanese pearl millet germplasm for agro-morphological traits and grain nutritional values. Plant Genet Res $12: 35-47$

Bashir EMA, Ali AM, Ali AM, Ismail MI, Parzies HK, Haussmann BIG (2014b) Patterns of pearl millet genotypeby-environment interaction for yield performance and grain quality traits in Sudan. Field Crops Res 166:82-91

Bashir EMA, Abdelbagi MA, Adam MA, Mohamed ETI, Melchinger AE, Parzies HK, Haussmann BIG (2015) Genetic diversity of Sudanese pearl millet (Pennisetum glaucum (L.) R. Br.) landraces as revealed by SSR markers, and relationship between genetic and agro-morphological diversity. Genet Resour Crop Evol 62:579-591. doi:10. 1007/s10722-014-0183-5

Baskaran K, Hash CT, Senthilvel S, Bhasker Raj AG, Muthiah AR (2009) SSR allele frequency changes in response to recurrent selection for pearl millet grain yield and other agronomic traits. J SAT Agric Res 7:8. http://oar.icrisat. org/577/

Baskaran K, Senthilvel S, Bhasker Raj AG, Chandra S, Muthiah A, Dhanapal AP, Hash CT (2014) Association analysis of SSR markers with phenology, grain and stover-yield related traits in pearl millet (Pennisetum glaucum (L.) R. Br.). Sci World J. doi:10.1155/2014/562327

Bationo A, Mokwunye AU (1991) Role of manures and crop residues in alleviating soil fertility constraints to crop production: with special reference to the Sahelian and Sudanian zones of West Africa. Fert Res 29:117-125

Bationo A, Mughogho SK, Mokwunye AU (1986) Agronomic evaluation of phosphate fertilizers in tropical Africa. In: Mokwunye AU, Vlek PLG (eds) Management of nitrogen and phosphorus fertilizers of sub-Saharan Africa. 
Developments in plant and soil sciences 24. Martinus Nijhoff, Dordrecht, pp 283-318

Bationo A, Chien SH, Henao J, Christianson BC, Mokwunye AU (1990) Agronomic evaluation of two unacidulated and partially acidulated phosphate rocks indigenous to Niger. Soil Sci Soc Am J 54:1772-1777

Beebe SE, Rojas-Pierce M, Yan X, Blair MW, Pedraza F, Munoz F, Tohme J, Lynch JP (2006) Quantitative trait loci for root architecture traits correlated with phosphorus acquisition in common bean. Crop Sci 46:413-423

Beebe SE, Rao IM, Cajiao C, Grajales M (2007) Selection for drought resistance in common bean also improves yield in phosphorus limited and favorable environments. Crop Sci 48:582-592

Benjamini Y, Hochberg Y (1995) Controlling the false discovery rate: a practical and multiple approach to multiple testing. J R Stat Soc 57(1):289-300

Bhattacharjee R, Khairwal IS, Bramel PJ, Reddy KN (2007) Establishment of a pearl millet [Pennisetum glaucum (L.) $\mathrm{R}$. Br.] core collection based on geographical distribution and quantitative traits. Euphytica 155:35-45

Bidinger FR, Serraj R, Rizvi SMH, Howarth C, Yadav RS, Hash CT (2005) Field evaluation of drought tolerance QTL effects on phenotype and adaptation in pearl millet [Pennisetum glaucum (L.) R. Br.] topcross hybrids. Field Crops Res 94:14-32

Bidinger FR, Nepolean T, Hash CT, Yadav RS, Howarth CJ (2007) Identification of QTLs for grain yield of pearl millet [Pennisetum glaucum (L.) $\mathrm{R} \mathrm{Br}$ ] in environments with variable moisture during grain filling. Crop Sci 47:969-980

Bolibok-Bragoszewska $\mathrm{H}$, Heller-Uszynska $\mathrm{K}$, Wenzl P, Uszynski G, Kilian A, Rakoczy-Trojanowska M (2009) DArT markers for the rye genome-genetic diversity and mapping. BMC Genomics 10:578

Bradbury PJ, Zhang Z, Kroon DE, Casstevens TM, Ramdoss Y, Buckler ES (2007) TASSEL: software for association mapping of complex traits in diverse samples. Bioinformatics 23(19):2633-2635

Breese WA, Hash CT, Devos KM, Howarth CJ (2002) Pearl millet genomics-an overview with respect to breeding for resistance to downy mildew. In: Leslie JF (ed) Sorghum and millets pathology 2000. Iowa State Press, Ames, pp 243-246

Brück H, Payne WA, Sattelmacher B (2000) Effects of phosphorus and water supply on yield, transpirational water-use efficiency, and carbon isotope discrimination in pearl millet. Crop Sci 40:120-125

Brück H, Sattelmacher B, Payne WA (2003) Varietal differences in shoot and rooting parameters of pearl millet on sandy soils in Niger. Plant Soil 251:175-185

Camus-Kulandaivelu L, Veyrieras JB, Madur D, Combes V, Fourmann M, Barraud S, Dubreuil P, Gouesnard B, Manicacci D, Charcosset A (2006) Maize adaptation to temperate climate: relationship between population structure and polymorphism in the Dwarf8 gene. Genetics 172:2449-2463

Chan EK, Rowe HC, Kliebenstein DJ (2010) Understanding the evolution of defense metabolites in Arabidopsis thaliana using genome-wide association mapping. Genetics 185(3):991-1007

Chen J, Xu L, Cai Y, Xu J (2009) Identification of QTLs for phosphorus utilization efficiency in maize (Zea mays L.) across P levels. Euphytica 167:245-252. doi:10.1007/ s10681-009-9883-x

Chen J, Cai Y, Xu L, Wang J, Zhang W, Wang G, Xu D, Chen T, Lu X, Sun H, Huang A, Liang Y, Dai G, Qin H, Huang Z, Zhu Z, Yang Z, Xu J, Kuang S (2011) Identification of QTLs for biomass production in maize (Zea mays L.) under different phosphorus levels at two sites. Front Agric China 5:152-161. doi:10.1007/s11703-011-1077-3

Clotault J, Thuillet A-C, Buiron M, De Mita S, Couderc M et al (2012) Evolutionary history of pearl millet (Pennisetum glaucum [L.] R. Br.) and selection on flowering genes since its domestication. Mol Biol Evol 29:1199-1212

Collins NC, Tardieu F, Tuberosa R (2008) Quantitative trait loci and crop performance under abiotic stress: where do we stand? Plant Physiol 147:469-486. doi:10.1104/pp.108. 118117

Cooper M, Delacy IH, Basford KE (1996) Relationships among analytical methods used to analyze genotypic adaptation in multi-environment trials. In: Cooper M, Hammer GL (eds) Plant adaptation and crop improvement. CAB International, Wallingford, pp 193-224

Earl DA, vonHoldt BM (2012) STRUCTURE HARVESTER: a website and program for visualizing STRUCTURE output and implementing the Evanno method. Conserv Genet Resour 4:359-361

Flint-Garcia SA, Thornsberry JM, Buckler ES (2003) Structure of linkage disequilibrium in plants. Annu Rev Plant Biol 54:357-374

Flint-Garcia SA, Thuillet A, Yu J, Pressoir G, Romero SM, Mitchell SE, Doebley J, Kresovich S, Goodman MM, Buckler ES (2005) Maize association population: a highresolution platform for quantitative trait locus dissection. Plant J 44:1054-1064

Gahoonia TS, Nielsen NE (2004) Root traits as tools for creating phosphorus efficient crop varieties. Plant Soil 260:47-57

Gemenet DC, Wachira FN, Pathak RS, Munyiri SW (2010) Identification of molecular markers linked to drought tolerance using bulked segregant analysis in Kenyan maize landraces (Zea mays L.). JAPS 9(1):1122-1134

Gemenet DC, Hash CT, Sy O, Zangre RG, Sanogo MD, Leiser WL, Parzies HK, Haussmann BIG (2014) Pearl millet inbred and testcross performance under low phosphorus in West Africa. Crop Sci 54:2574-2585

Gemenet DC, Hash CT, Sanogo MD, Sy O, Zangre RG, Leiser WL, Haussmann BIG (2015a) Phosphorus uptake and utilization efficiency in West African pearl millet inbred lines. Field Crops Res 171:54-66

Gemenet DC, Beggi F, Hash CT, Sy O, Sanogo MD, Zangre RG, Falalou H, Buerkert A, Haussmann BIG (2015b) Towards understanding the traits contributing to performance of pearl millet open-pollinated varieties in phosphorus-limited environments of West Africa. Plant Soil (in press)

Goswami AK, Sharma KP, Sehgal KI (1969) Nutritive value of proteins of pearl millet of high-yielding varieties and hybrids. Br J Nutr 23:913-916

Gulia SK, Hash CT, Thakur RP, Breese WA, Sangwan RS (2007) Mapping new QTLs for downy mildew [Sclerospora graminicola (Sacc.) J. Schroet.] resistance in pearl millet (Pennisetum glaucum (L.) R. Br.). In: Singh DP, Tomar VS, Behl RK, Upadhyaya SD, Bhale MS, Khare K (eds) Crop production in stress environments-genetic and 
management options. Agrobios Publishers, Jodhpur, pp 373-386

Gupta SK, Nepolean T, Rai KN, Hash CT, Bhattacharjee R, Rathore A (2012) Within-line genetic variation for quantitative characters and SSRs in long-time maintained inbreds in pearl millet [Pennisetum glaucum (L). R. Br.]. Eur J Plant Sci Biotech 6(SI 2):109-113

Haesler S (2012) Drought with subsequent floods in the area of Sahel West Africa 2011/2012. http://www.dwd.de/bvbw/ generator/DWDWWW/Content/Oeffentlichkeit/KU/KU2/ KU24/besondere_ereignisse_global/niederschlaege/engli scheberichte/2012_drought_Sahel,templateId=raw, proper ty=publicationFile.pdf/2012_drought_Sahel.pdf. Accessed Dec 2014

Hao D, Cheng H, Yin Z, Cui S, Zhang D, Wang H, Yu D (2012) Identification of single nucleotide polymorphisms and haplotypes associated with yield and yield components in soybean (Glycine max) landraces across multiple environments. Theor Appl Genet 124:447-458

Harlan J, De Wet J, Stemler A (1976) Origins of African plant domestication. Mouton Publishers, La Hague

Hash CT, Witcombe JR (2001) Pearl millet molecular marker research. Int Sorghum Millets Newsl 42:8-15 (published 2005)

Hash CT, Cavan GP, Bidinger FR, Howarth CJ, Singh SD (1995) Downy mildew resistance QTLs from a seedling heat tolerance mapping population. Int Sorghum Millets Newsl 36:66-67

Hash CT, Schaffert RE, Peacock JM (2002) Prospects for using conventional techniques and molecular biological tools to enhance performance of 'orphan' crop plants on soils low in available phosphorus. Plant Soil 245:135-146

Hash CT, Bhasker Raj AG, Lindup S, Sharma A, Beniwal CR, Folkertsma RT, Mahalakshmi V, Zerbini E, Blümmel M (2003) Opportunities for marker-assisted selection (MAS) to improve the feed quality of crop residues in pearl millet and sorghum. Field Crop Res 84:79-88

Hash CT, Thakur RP, Rao VP, Bhasker Raj AG (2006a) Evidence for enhanced resistance to diverse isolates of pearl millet downy mildew through gene pyramiding. Int Sorghum Millets Newsl 47:134-138

Hash CT, Sharma A, Kolesnikova-Allen MA, Singh SD, Thakur RP, Bhasker Raj AG, Ratnaji Rao MNV, Nijhawan DC, Beniwal CR, Sagar P, Yadav HP, Yadav YP, Srikant S, Bhatnagar SK, Khairwal IS, Howarth CJ, Cavan GP, Gale MD, Liu C, Devos KM, Breese WA, Witcombe JR (2006) Teamwork delivers biotechnology products to Indian small-holder crop-livestock producers: Pearl millet hybrid "HHB 67 Improved" enters seed delivery pipeline. SAT eJ 2(1). http://www.icrisat.org/Journal/bioinformatics/v2i1/ v2i1teamwork.pdf

Haussmann BIG, Rattunde HF, Weltzien-Rattunde E, Traore PSC, vom Brocke K, Parzies HK (2012) Breeding strategies for adaptation of pearl millet and sorghum to climate variability and change in West Africa. J Agron Crop Sci 198:327-339. doi:10.1111/j.1439-037X.2012.00526.x

Hedrick PW (2005) Genetics of populations. Jones and Bartlett Publishers, Massachusetts, p 737

Hufnagel B, de Sousa SM, Assis L et al (2014) Duplicate and conquer: multiple homologs of phosphorus-starvation tolerance 1 enhance phosphorus acquisition and sorghum performance on low-phosphorus soils. Plant Physiol 166:659-677

Hurtado P, Olsen KM, Buitrago C, Ospina C, Marin J, Duque M, de Vicente C, Wongtiem P, Wenzel P, Kilian A, Adeleke M, Fregene M (2008) Comparison of simple sequence repeat (SSR) and diversity array technology (DArT) markers for assessing genetic diversity in cassava (Manihot esculenta Crantz). Plant Genet Resour Charact Util 6(3):208-214

Jaccoud D, Peng K, Feinstein D, Kilian A (2001) Diversity arrays: a solid state technology for sequence information independent genotyping. Nucleic Acids Res 29(4):e25

Jakobsson M, Rosenberg NA (2007) CLUMPP: a cluster matching and permutation program for dealing with label switching and multimodality in analysis of population structure. Bioinformatics 23:1801-1806

Jing H-C, Bayon C, Kanyuka K, Berry S, Wenzl P, Huttner E, Kilian A, Hammond-Kosack KE (2009) DArT markers: diversity analyses, genomes comparison, mapping and integration with SSR markers in Triticum monococcum. BMC Genomics 10:458. doi:10.1186/1471-2164-10-458

Jones ES, Liu CJ, Gale MD, Hash CT, Witcombe JR (1995) Mapping quantitative trait loci for downy mildew resistance in pearl millet. Theor Appl Genet 91:448-456

Jones ES, Breese WA, Liu CJ, Singh SD, Shaw DS, Witcombe JR (2002) Mapping quantitative trait loci for resistance to downy mildew in pearl millet. Crop Sci 42:1316-1323. doi:10.2135/cropsci2002.1316

Kapila RK, Yadav RS, Plaha P, Rai KN, Yadav OP, Hash CT, Howarth CJ (2008) Analysis of genetic diversity in pearl millet inbreds using microsatellite markers. Plant Breed 127(1):33-37. doi:10.1111/j.1439-0523.2007.01433.x

Kenward MG, Roger JH (1997) Small sample inference for fixed effects from restricted maximum likelihood. Biometrics 53(3):983-997

Khairwal IS, Hash CT (2007) "HHB 67-Improved"-the first product of marker-assisted crop breeding in India. AsiaPacific Consortium on Agricultural Biotechnology (APCoAB) e-News. http://www.apcoab.org/special_news. html

Kholová J, Hash CT, Kakkera A, Kočová M, Vadez V (2010a) Constitutive water-conserving mechanisms are correlated with the terminal drought tolerance of pearl millet [Pennisetum glaucum (L.) R. Br.]. J Exp Bot 61:369-377. doi:10.1093/jxb/erp314

Kholová J, Hash CT, Lava Kumar P, Yadav RS, Kočová M, Vadez V (2010b) Terminal drought tolerant pearl millets [Pennisetum glaucum (L.) R. Br.] have high leaf ABA and limit transpiration at high vapor pressure deficit. J Exp Bot 61:1431-1440

Kholová J, Nepolean T, Hash CT, Supriya A, Rajaram V, Senthilvel S, Kakkera A, Yadav RS, Vadez V (2012) Water saving traits co-map with a major terminal drought tolerance quantitative trait locus in pearl millet (Pennisetum glaucum (L.) R. Br.). Mol Breed 30:1337-1353. doi:10. 1007/s11032-012-9720-0

King KE, Lauter N, Lin SF, Scott MP, Shoemaker RC (2013) Evaluation and QTL mapping of phosphorus concentration in soybean seed. Euphytica 189:261-269

Kraakman ATW, Niks RE, Van den Berg PMMM, Piet Stam P, van Eeuwijk FA (2004) Linkage disequilibrium mapping 
of yield and yield stability in modern spring barley cultivars. Genetics 168:435-446. doi:10.1534/genetics.104. 026831

Lakis G, Navascués M, Rekima S, Simon M, Remigereau M-S, Leveugle M, Takvorian N, Lamy F, Depaulis F, Robert T (2012) Evolution of neutral and flowering genes along pearl millet (Pennisetum glaucum) domestication. PLoS ONE 7:e36642. doi:10.1371/journal.pone.0036642

Lebreton C, LazicJancic V, Steed A, Pekic SQS (1995) Identification of QTL for drought responses in maize and their use in testing causal relationships between traits. J Exp Bot 46:853-865

Leiser WL, Rattunde HFW, Piepho HP, Weltzien E, Diallo A, Melchinger AE, Parzies HK, Haussmann BIG (2012) Selection strategy for sorghum targeting phosphorus limited environments in West Africa: analysis of multi-environment experiments. Crop Sci 52:2517-2527

Leiser WL, Rattunde HFW, Weltzien E, Cisse N, Abdou M, Diallo A, Tourè AO, Magalhaes JV, Haussmann BIG (2014) Two in one sweep: aluminum tolerance and grain yield in P-limited soils are associated to the same genomic region in West African sorghum. BMC Plant Biol 14:206. http://www.biomedcentral.com/1471-2229/14/206

Lewis LR (2010) Biogeography and genetic diversity of pearl Millet (Pennisetum glaucum) from Sahelian Africa. Prof Geogr 62:377-394

Li YD, Wang YJ, Tong YP, Gao JG, Zhang JS, Chen SY (2005) QTL mapping of phosphorus deficiency tolerance in soybean (Glycine max L. Merr.). Euphytica 142:137-142. doi:10.1007/s10681-005-1192-4

Li M, Guo X, Zhang M, Wang X, Zhang G, Tian Y, Wang Z (2010) Mapping QTLs for grain yield and yield components under high and low phosphorus treatments in maize (Zea mays L.). Plant Sci 178:454-462. doi:10.1016/j. plantsci.2010.02.019

Mace ES, Xia L, Jordan DR, Halloran K, Parh DK, Huttner E, Wenzl P, Kilian A (2008) DArT markers: diversity analyses and mapping in Sorghum bicolor. BMC Genom 9:26

Manning K (2011) 4500-Year old domesticated pearl millet (Pennisetum glaucum) from the Tilemsi Valley, Mali: new insights into an alternative cereal domestication pathway. J Archaeol Sci. doi:10.1016/j.jas.2010.09.007

Mariac C, Luong V, Kapran I, Mamadou A, Sagnard F, Deu M, Chantereau J, Gerard B, Ndjeunga J, Bezancon G, Pham J-L, Vigouroux Y (2006) Diversity of wild and cultivated pearl millet accessions (Pennisetum glaucum [L.] R. Br.) in Niger assessed by microsatellite markers. Theor Appl Genet 114:49-58. doi:10.1007/s00122-006-0409-9

Mendes FF, Guimarães LJM, Souza JC, Guimarães PEO, Magalhaes JV, Garcia AAF, Parentoni SN, Guimaraes C (2014) Genetic architecture of phosphorus use efficiency in tropical maize cultivated in a low $\mathrm{P}$ soil. Crop Sci 54:1530-1538. doi:10.2135/cropsci2013.11.0755

Muehlig-Versen B, Buerkert A, Bationo A, Roemheld V (2003) Phosphorus placement on acid arenosols of the West African Sahel. Exp Agric 39:307-325

Nepolean T, Blümmel M, Hash CT (2009) Improving straw quality traits through QTL mapping and marker-assisted selection in pearl millet. In: Forage symposium 2009emerging trends in forage research and livestock production, February 16-17, p 12
Nepolean T, Gupta SK, Dwivedi SL, Bhattacharjee R, Rai KN, Hash CT (2012) Genetic diversity in maintainer and restorer lines of pearl millet. Crop Sci 52:2555-2563

Oumar I, Mariac C, Pham JL, Vigouroux Y (2008) Phylogeny and origin of pearl millet (Pennisetum glaucum [L.] R. Br.) as revealed by microsatellite loci. Theor Appl Genet 117:489-497

Parentoni S, de Souza Jr C, de Carvalho Alves V et al (2010) Inheritance and breeding strategies for phosphorus efficiency in tropical maize (Zea mays L.). Maydica 55:1-15

Pasam RK, Sharma R, Malosetti M, van Eeuwijk FA, Haseneyer G, Kilian B, Graner A (2012) Genome-wide association studies for agronomical traits in a world-wide spring barley collection. BMC Plant Biol 12:16. http://www. biomedcentral.com/1471-2229/12/16

Payne WA, Lascano RJ, Hossner LR, Wendt CW, Onken AB (1991) Pearl millet growth as affected by phosphorus and water. Agron J 83:942-948

Payne WA, Hossner LR, Onken AB, Wendt CW (1995) Nitrogen and phosphorus uptake in pearl millet and its relation to nutrient and transpiration efficiency. Agron J 87:425-431

Perrier X, Jacquemoud-Collet JP (2006) DARwin software. http://darwin.cirad.fr/darwin

Piepho H-P, Möhring J (2007) Computing heritability and selection response from unbalanced plant breeding trials. Genetics 177:1881-1888

Piepho H-P, Möhring J, Schulz-Streeck T, Ogutu JO (2012) A stage-wise approach for the analysis of multi-environment trials. Biom J 54(6):844-860

Pritchard JK, Stephens M, Donnelly P (2000) Inference of population structure using multi-locus genotype data. Genetics 155:945-959

Pucher A, Hogh-Jensen H, Gondah J, Hash CT, Haussmann BIG (2014) Micronutrient density and stability in West African pearl millet-potential for biofortification. Crop Sci 54:1709-1720

Pucher A, Sy O, Angarawai II, Gondah J, Zangre R, Ouedraogo M, Sanogo MD, Boureima S, Hash CT, Haussmann BIG (2015) Agro-morphological characterization of West and Central African pearl millet accessions. Crop Sci. doi:10. 2135/cropsci2014.06.0450

Rai KN, Rao AS, Hash CT (1995) Registration of pearl millet parental lines ICMA 88004 and ICMB 88004. Crop Sci $35: 1242$

Rai KN, Hash CT, Singh AK, Velu G (2008) Adaptation and quality traits of a germplasm-derived commercial seed parent of pearl millet. Plant Genet Resour Newsl 154:20-24

Raman R, Cowley RB, Raman H, Luckett DJ (2014) Analyses using SSR and DArT molecular markers reveal that Ethiopian accessions of white lupin (Lupinus albus L.) represent a unique genepool. Open J Genet 4:87-98. doi:10.4236/ojgen.2014.42012

Ramdoss Y, Oak ME, Holmberg KJ, Stevens N, Zhang Y (2011) User manual for TASSEL-Trait Analysis by aSSociation, evolution and linkage version 3.0. The Buckler Lab at Cornell, $73 \mathrm{pp}$

Rebafka F-P, Hebel A, Bationo A, Stahr K, Marschner S (1994) Short- and long-term effects of crop residues and of phosphorus fertilization on pearl millet yield on an acid sandy soil in Niger, West Africa. Field Crops Res $36: 113-124$ 
Reiter RS, Coors JG, Sussman MR, Gabelman WH (1991) Genetics analysis of tolerance to low-phosphorus stress in maize using RFLP. Theor Appl Genet 82:561-568

Rose TJ, Pariasca-Tanaka J, Rose MT, Fukuta Y, Wissuwa M (2010) Genotypic variation in grain phosphorus concentration, and opportunities to improve P-use efficiency in rice. Field Crop Res 119:154-160

Sabadin PK, Malosetti M, Boer MP, Tardin FD, Santos FG, Guimarães CT, Gomide RL, Andrade CLT, Albuquerque PEP, Caniato FF, Mollinari M, Margarido GRA, Oliveira BF, Schaffert RE, Garcia AAF, van Eeuwijk FA, Magalhaes JV (2012) Studying the genetic basis of drought tolerance in sorghum by managed stress trials and adjustments for phonological and plant height differences. Theor Appl Genet 124:1389-1402. doi:10.1007/s00122012-1795-9

Saidou AA, Mariac C, Luong V, Pham J-L, Bezancon G et al (2009) Association studies identify natural variation at PHYC linked to flowering time and morphological variation in pearl millet. Genetics 182:899-910

Saidou AA, Clotault J, Couderc M, Mariac C, Katrien M, Devos KM, Thuillet AC, Ibrahim A, Amoukou IA, Vigouroux Y (2014) Association mapping, patterns of linkage disequilibrium and selection in the vicinity of the PHYTOCHROME C gene in pearl millet. Theor Appl Genet 127:19-32. doi:10.1007/s00122-013-2197-3

SAS Institute (2015) SAS Institute Inc., SAS Campus Drive, Cary, North Carolina 27513-2414

Sawaya WN, Khalil JK, Safi WJ (1984) Nutritional quality of pearl-millet flour and bread. Plant Foods Hum Nutr 34:117-125

Schaffert RE, Alves VMC, Parentoni SN, Raghothama KG (2000) Genetic control of phosphorus uptake and utilization efficiency in maize and sorghum under marginal soil conditions. In: Ribaut JM, Poland D (eds) Molecular approaches for the genetic improvement of cereals for stable production in water-limited environments. A strategic planning workshop held at CIMMYT, El Batan, Mexico, 21-25 June 1999. International Maize and Wheat Improvement Center (CIMMYT), Mexico, DF, Mexico, pp 79-85

Sehgal D, Rajaram V, Armstead IP, Vadez V, Yadav YP, Hash CT, Yadav RS (2012) Integration of gene-based markers in a pearl millet genetic map for identification of candidate genes underlying drought tolerance quantitative trait loci. BMC Plant Biol 12:9. http://www.biomedcentral.com/ 1471-2229/12/9

Serraj R, Hash CT, Rizvi SMH, Sharma A, Yadav RS, Bidinger FR (2005) Recent advances in marker-assisted selection for drought tolerance in pearl millet. Plant Prod Sci 8:332-335

Sharma PC, Singh D, Sehgal D, Singh G, Hash CT, Yadav RS (2014) Further evidence that a terminal drought tolerance QTL of pearl millet is associated with reduced salt uptake. Environ Exp Bot 102:48-57. doi:10.1016/j.envexpbot. 2014.01.013

Stegmeier WD, Andrews DJ, Rai KN (1998a) Pearl millet parental lines 842A and 842B. Int Sorghum Millets Newsl 39:128-129

Stegmeier WD, Andrews DJ, Rai KN, Hash CT (1998b) Pearl millet parental lines 843A and 843B. Int Sorghum Millets Newsl 39:129-130
Stich B, Möhring J, Piepho H-P, Heckenberger M, Buckler ES, Melchinger AE (2008) Comparison of mixed-model approaches for association mapping. Genetics 178:1745-1754. doi:10.1534/genetics.107.079707

Stich B, Haussmann BIG, Pasam R, Bhosale S, Hash CT, Melchinger AE, Parzies HK (2010) Patterns of molecular and phenotypic diversity in pearl millet [Pennisetum glaucum (L.) R. Br.] from West and Central Africa and their relation to geographical and environmental parameters. BMC Plant Biol 10:1-10. doi:10.1186/1471-2229-10-216

Su JY, Zheng Q, Li HW, Li B, Jing RL, Tong YP, Li ZS (2009) Detection of QTLs for phosphorus use efficiency in relation to agronomic performance in wheat grown under phosphorus sufficient and limited conditions. Plant Sci 176:824-836

Subbarao GV, Renard C, Payne WA, Batiano A (2000) Longterm effects of tillage, phosphorus fertilization and crop rotation on pearl millet-cowpea productivity in the WestAfrican Sahel. Exp Agric 36:243-264

Supriya A, Senthilvel S, Nepolean T, Eshwar K, Rajaram V, Shaw R, Hash CT, Kilian A, Yadav RC, Narasu ML (2011) Development of a molecular linkage map of pearl millet integrating DArT and SSR markers. Theor Appl Genet 123:239-250. doi:10.1007/s00122-011-1580-1

Tinker NA, Kilian A, Wight CP, Heller-Uszynska K, Wenzl P, Rines HW, Bjørnstad A, Howarth CJ, Jannink JL, Anderson JM, Rossnage BG, Stuthman DD, Sorrells ME, Jackson EW, Tuvesson S, Kolb FL, Olsson O, Federizzi LC, Carson ML, Ohm HW, Molnar SJ, Scoles GJ, Eckstein PE, Bonman JM, Ceplitis A, Langdon T (2009) New DArT markers for oat provide enhanced map coverage and global germplasm characterization. BMC Genomics 10:39

Tostain S (1992) Enzyme diversity in pearl millet (Pennisetum glaucum L.) 3. Wild millet. Theor Appl Genet 83:733-742

Tostain S, Riandley MF, Marchais L (1987) Enzyme diversity in pearl millet (Pennisetum glaucum). 1. West Africa. Theor Appl Genet 74:188-193

Tuberosa R, Sanguineti MC, Landi P, Giuliani MM, Salvi S, Conti S (2002) Identification of QTLs for root characteristics in maize grown in hydroponics and analysis of their overlap with QTLs for grain yield in the field at two water regimes. Plant Mol Biol 48:697-712

Valluru R, Vadez V, Hash CT, Karanam P (2010) A minute phosphorus application contributes to a better establishment of pearl millet (Pennisetum glaucum (L.) R.Br.) seedling in phosphorus deficient soils. Soil Use Manag $26: 36-43$

VDLUFA (2011) Umweltanalytik. VDLUFA-Verlag, Darmstadt

Via S, Gomulkiewicz R, De Jong G, Scheiner SM, Schlichting CD et al (1995) Adaptive phenotypic plasticity: consensus and controversy. Trends Ecol Evol 10:212-217

Vigouroux Y, Mitchell S, Matsuoka Y, Hamblin M, Kresovich S, Smith JS, Jaqueth J, Smith OS, Doebley J (2005) An analysis of genetic diversity across the maize genome using microsatellites. Genetics 169:1617-1630

Weir CC (1972) Phosphate studies on the Jamaican bauxite soils. Trop Agric (Trinidad) 49:89-96

Weir CC (1977) Phosphate fixation in Jamaican latosolic soils. Soil Sci Soc Am Proc 30:653-655

Wenzl P, Kudrna D, Jaccoud D, Huttner E, Kleinhofs A, Kilian A (2004) Diversity arrays technology (DArT) for whole 
genome profiling of barley. Proc Natl Acad Sci USA 101(26):9915-9920

Wissuwa M, Yano M, Ae N (1998) Mapping of QTLs for phosphorus-deficiency tolerance in rice (Oryza sativa L.). Theor Appl Genet 97:777-783

Wissuwa M, Wegner J, Ae N, Yano M (2002) Substitution mapping of Pup1: a major QTL increasing phosphorus uptake of rice from a phosphorus-deficient soil. Theor Appl Genet 105:890-897

Xia L, Peng K, Yang S, Wenzl P, Carmen de Vicente M, Fregene M, Kilian A (2005) DArT for high-throughput genotyping of cassava (Manihot esculenta) and its wild relatives. Theor Appl Genet 110:1092-1098

Yadav RS, Hash CT, Bidinger FR, Cavan GP, Howarth CJ (2002) Quantitative trait loci associated with traits determining grain and stover yield in pearl millet under terminal drought-stress conditions. Theor Appl Genet 104(1):67-83

Yadav RS, Bidinger FR, Hash CT, Yadav YP, Yadav OP, Bhatnagar SK, Howarth CJ (2003) Mapping and characterisation of QTL $\times \mathrm{E}$ interactions for traits determining grain and stover yield in pearl millet. Theor Appl Genet 106(3):512-520

Yadav RS, Hash CT, Bidinger FR, Devos KM, Howarth CJ (2004) Genomic regions associated with grain yield and aspects of post-flowering drought tolerance in pearl millet across stress environments and tester background. Euphytica 136:265-277

Yadav R, Sehgal D, Vadez V (2011) Using genetic mapping and genomics approaches in understanding and improving drought tolerance in pearl millet. J Exp Bot 62:397-408

Yan W, Kang MS (2002) GGE biplot analysis: a graphical tool for breeders, geneticists, and agronomists, 1st edn. CRC Press, Boca Raton

Yan X, Liao L, Trull MC, Beebe SE, Lynch JP (2001) Induction of a major leaf acid phosphatase does not confer adaptation to low phosphorus availability in common bean. Plant Physiol 125:1901-1911
Yang S, Pang W, Harper J, Carling J, Wenzl P, Huttner E, Zong X, Kilian A (2006) Low level of genetic diversity in cultivated pigeon pea compared to its wild relatives is revealed by diversity arrays technology. Theor Appl Genet 113:585-595

Yu J, Buckler ES (2006) Genetic association mapping and genome organization of maize. Curr Opin Biotechnol 17:155-160

Yu J, Pressoir G, Briggs WH, Bi IV, Yamasaki M et al (2006) A unified mixed-model method for association mapping that accounts for multiple levels of relatedness. Nat Genet 38:203-208

Zaongo CGL, Hossner LR, Wendt CW (1994) Root distribution, water use and nutrient uptake of millet and grain sorghum on West African soils. Soil Sci 157:379-388

Zhang D, Cheng H, Geng L, Kan G, Cui S, Meng Q, Gai J, Yu D (2009) Detection of quantitative trait loci for phosphorus deficiency tolerance at soybean seedling stage. Euphytica 167:313-322

Zhang L, Liu D, Guo X, Yang W, Sun J, DaoWen Wang D, Sourdille P, AiMin Zhang A (2011) Investigation of genetic diversity and population structure of common wheat cultivars in northern China using DArT markers. BMC Genetics 12:42. http://www.biomedcentral.com/ $1471-2156 / 12 / 42$

Zhang H, Uddin MS, Zou C, Xie C, Xu Y, Li WX (2014) Meta analysis and candidate gene mining of low phosphorus tolerance in maize. J Integr Plant Biol 56:262-270. doi:10. 1111 jipb. 12168

Zhao K, Aranzana MJ, Kim S, Lister C, Shindo C et al (2007) An Arabidopsis example of association mapping in structured samples. PLoS Genet 3:71-82

Zhu C, Gore M, Buckler ES, Yu J (2008) Status and prospects of association mapping in plants. Plant Genome 1:5-20. doi:10.3835/plantgenome2008.02.0089 